\title{
Infection in Athletes
}

\section{Ingrid K.M. Brenner, Pang N. Shek and Roy J. Shephard}

School of Physical and Health Education, Graduate Programme in Exercise Sciences, Division of Community Health, University of Toronto, Toronto, Ontario, and Defence and Civil Institute of Environmental Medicine, North York, Ontario, Canada

\section{Contents}

86
87
87
88
88
89
90
90
90
92
92
92
96
98
100
100
101
101
102

Summary

1. The Immune System

1.1 Cells and Soluble Factors

1.2 Innate and Adaptive Immunity

1.3 General Scheme of the Immune Response

1.4 Infection

2. Influence of Exercise on Immune Function

2.1 Exercise and Innate Immunity

2.2 Exercise and Adaptive Immunity

2.3 Hormonal Effects

3. Physical Activity and Infection

3.1 Upper Respiratory Tract Infections

3.2 Cutaneous Infections

3.3 Other Infections

4. Exercising Before and During an Acute Infectious Illness

4.1 Morbidity and Mortality

4.2 Decrements in Physical Performance

5. Clinical Implications

6. Conclusions

Summary

Coaches and athletic team physicians have provided anecdotal information and case studies to support their beliefs that athletes may be unusually prone to illness during strenuous training or competition. Many athletes, in contrast, believe that physical activity improves their resistance to infectious disease. However, it is generally agreed that the stress of competition may make athletes temporarily more susceptible to infectious illness. A review of the literature shows that upper respiratory tract infections and skin infections are more prevalent in top level athletes than in the general population, particularly during periods of intensive training. Exercise induced changes occur in both the innate and adaptive components of the immune system; however, the relative importance of each component is unknown. Strenuous exertion and contact sports may compromise host defence both by reducing physical protection and by impairing immunosurveillance. Skin lacerations, vigorous sweating and maceration of the dermis impair the defence normally provided by the skin surface. In addition, adverse changes in soluble and cellular components of the immune system can increase susceptibility to infection. Persistence with strenuous training during an infectious illness can have deleterious effects; not only is athletic performance impaired, but the severity of the disease process can be augmented. 
Elite athletes train mainly to improve sport specific components of skill and physical fitness (Niinimaa 1982) and others participate in regular physical activity to reap physiological, psychological and health benefits (Morgan 1985; Paffenbarger et al. 1984, 1993). Regular physical activity generally has positive effects on the cardiorespiratory and musculoskeletal systems and it often induces positive changes in mood state. However, controversy exists regarding the acute and chronic effects of physical activity on the immune system and thus, resistance to disease (Fry et al. 1991a,b; Keast \& Morton 1992; Mackinnon 1992; Nash 1986; Verde 1992).

Recent research suggests that although regular participation in moderate exercise has an immunoenhancing effect, very strenuous exercise and high levels of athletic competition may suppress immune function, increasing susceptibility to infections (Cannon 1993; Eichner 1993; Fitzgerald 1991; Heath et al. 1992; Liesen \& Uhlenbruck 1992; Linde 1987; Linenger et al. 1993; Nash 1986; Nieman \& Nehlsen-Cannarella 1992; Nieman et al. 1989b, 1990a,b; Simon 1987). Infections are often associated with a reduction in athletic performance and can have permanent or lethal consequences (Daniels et al. 1985; Jokl 1974; Midtvedt \& Midtvedt 1982; Munschek 1976; Roberts 1986).

As a result of the training methods of athletes, the physical and psychological environments encountered and the consequences of musculoskeletal injuries, certain types of infection are more common in athletes than in the general population (Diop Mar 1988; Midtvedt \& Midtvedt 1982). This review provides an overview of the immune system and its role in infection and summarises the types of infections where athletes are at increased risk and the postulated mechanisms that enhance their susceptibility.

\section{The Immune System}

The immune system protects against, recognises, attacks and destroys elements which are foreign to the body. It comprises innate (naturally occurring) and adaptive (acquired) components which work together in a coordinated manner (Nieman \& Nehlsen-Cannarella 1991; Roitt et al. 1985) [table I]. The first line of defence, the innate immune system, is encountered immediately when an infectious agent attempts to enter the body (Roitt et al. 1985). If this system fails, an acute infection may result and the adaptive immune system is activated. The adaptive immune system helps the body to recover from the infection and develops a 'memory' for the infectious agent, decreasing the likelihood of reinfection (Roitt et al. 1985).

\subsection{Cells and Soluble Factors}

Both cells and soluble factors contribute to the immune response. The white cell population (leucocytes) consists of granulocytes, lymphocytes and monocytes. Granulocytes (neutrophils, eosinophils and basophils) normally account for 60 to $70 \%$ of circulating leucocytes and 20 to $25 \%$ of circulating leucocytes are lymphocytes. Various subsets within the lymphocyte cell population have been identified through the use of monoclonal antibodies, which bind to unique cell surface proteins (cluster designators, CD) [Mackinnon 1992]. Important subsets of the T cell population (CD3) include $\mathrm{T}$ helper cells (CD4) and $\mathrm{T}$ cytotoxic/suppressor cells (CD8). Other lymphocytes include the B cells (CD19) and natural killer (NK) cells (CD16).

The B cells and plasma cells produce and secrete immunoglobulins which can be assayed in serum and other body fluids (for example, the saliva). There are 5 major groups of immunoglobins: $\operatorname{IgA}, \operatorname{IgG}, \operatorname{Ig} M, \operatorname{IgD}$ and $\operatorname{IgE}$. IgG and $\operatorname{IgM}$ are found predominantly in the serum, whereas secre-

Table I. Major elements of innate and adaptive immunity (Nieman \& Nehlsen-Cannarella 1991; Roitt et al. 1985)

\begin{tabular}{lll}
\hline & Innate immunity & $\begin{array}{l}\text { Adaptive } \\
\text { immunity }\end{array}$ \\
\hline Soluble factors & $\begin{array}{l}\text { Complement } \\
\text { Acute phase proteins } \\
\text { Lysozyme }\end{array}$ & Antibodies \\
Cells & $\begin{array}{l}\text { Phagocytes (macrophages, } \\
\text { monocytes, neutrophils) }\end{array}$ & $\begin{array}{l}\text { T lymphocytes } \\
\text { B lymphocytes }\end{array}$ \\
& Natural killer cells & \\
\hline
\end{tabular}


tory $\operatorname{Ig} \mathrm{A}$ is found mainly in mucosal fluids. When immunoglobulin molecules have a capacity to react with specific antigens they are described as antibodies. Antibodies protect the host by combining with surface antigens and agglutinising micro-organisms, facilitating phagocytosis, activating the complement system, producing opsonins and neutralising bacterial toxins (Mackinnon 1992).

Other soluble factors include cytokines, complement and acute phase proteins. Cytokines are proteins involved in the communication between different immune cells; they include interleukins, interferons, tumour necrosis and colony-stimulating factors, each with diverse functions. Complement is a system of at least 20 proteins that stimulate phagocytosis, antigen presentation and the killing of infected cells. Acute phase proteins are involved in immune and inflammatory responses (Kumar et al. 1992), encouraging cell migration to sites of infection and injury, activating complement, stimulating phagocytosis and minimising tissue injury.

\subsection{Innate and Adaptive Immunity}

The innate immune system restricts entry of micro-organisms into the body through physical and chemical barriers plus phagocytosis by selected cells (Mackinnon 1992). The physical barriers to micro-organisms include the skin, epithelial linings and mucus secretions. The $\mathrm{pH}$ of body fluids

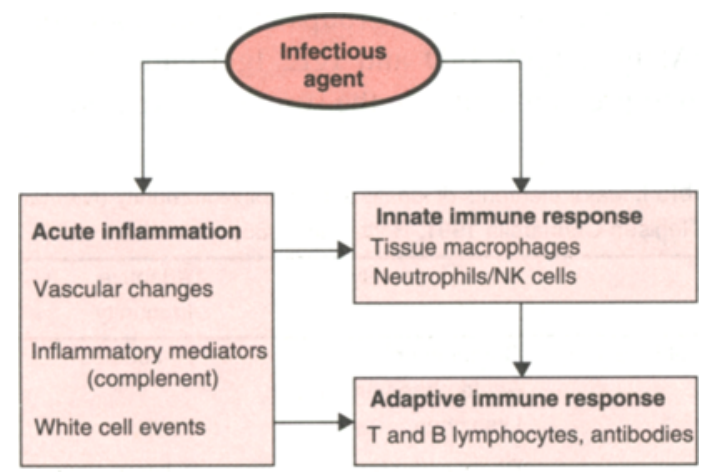

Fig. 1. Relationship between inflammatory and immune responses. Abbreviation: $\mathrm{NK}=$ natural killer. and soluble factors such as complement, acute phase proteins and lysozyme create an adverse chemical environment for the invading micro-organism. Finally, neutrophils and macrophages can phagocytose and destroy bacteria either in the surface secretions or after penetration of the physical and chemical barriers.

The adaptive immune system depends on the body's ability to recognise antigens on an invading micro-organism. It, also, involves cells and soluble factors: T cells, B cells and immunoglobulins. Activation of lymphocytes ( $\mathrm{T}$ cells) induces an alteration in their design to destroy the specific invading micro-organism. B cells secrete immunoglobulins specific for the antigens presented by the invading micro-organism, and in the process acquire a 'memory' of the exposure that facilitates the response to a subsequent challenge by the same micro-organism.

\subsection{General Scheme of the Immune Response}

Inflammation works in concert with the immune response to eliminate infectious microorganisms (Kumar et al. 1992) [fig. 1]. The body's immediate response to infection is acute inflammation. Blood flow is increased to the infected area and vascular permeability is augmented to facilitate the entry of leucocytes and plasma proteins into the infected tissue.

Details of the immune response vary, depending upon the type of infection (parasitic, bacterial, fungal or viral), but the general pattern of response is similar (fig. 2). The process is initiated when a macrophage engulfs an invading micro-organism. The micro-organism is killed by lysozymes and/or oxidising agents released from within the macrophage. Foreign proteins, normally found on the surface of the micro-organism, are processed by the macrophage and are incorporated into its own cell surface, where they can be presented to other cellular components of the immune system.

T-helper (CD4) cells play a major role in coordinating the immune response. Once they recognise antigen-presenting or virally infected cells, they release cytokines to activate other immune 


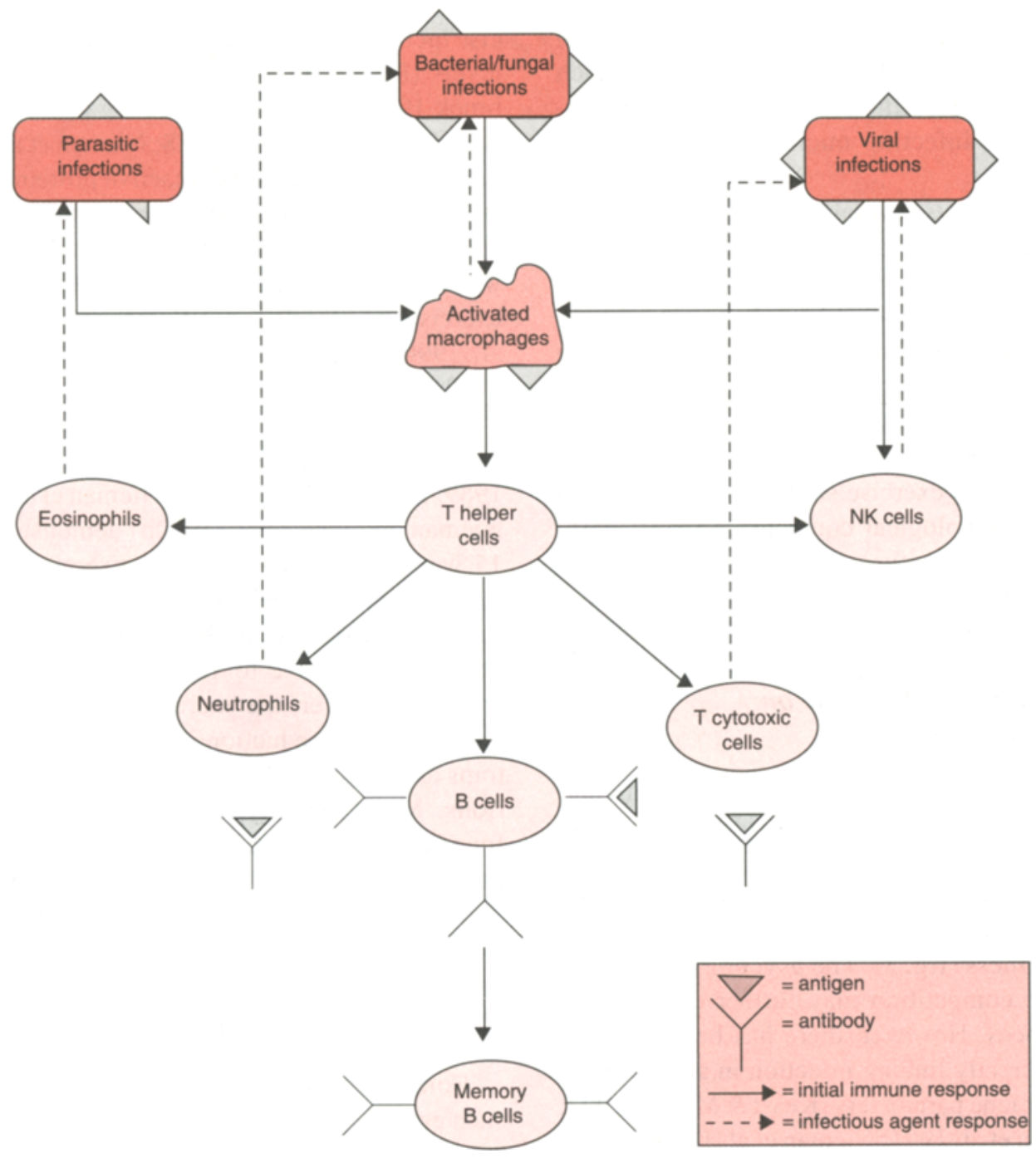

Fig. 2. General scheme of the immune response to various infectious agents [from Roitt et al. (1985) and Mackinnon (1992), with permission]. Abbreviation: $\mathrm{NK}=$ natural killer.

cells. They also stimulate B lymphocytes to secrete antibodies and to become memory $B$ cells.

The type of infectious agent will determine which component of the immune response will predominate (Thong 1986). Phagocytic cells (macrophages and neutrophils) play a major role in the defence against bacteria and fungi. Eosinophils are important in the elimination of parasites, whereas cell-mediated immune mechanisms involving $\mathrm{T}$ cells predominate in the defense against viruses.
The cytokines (interleukin-1, interferon- $\alpha$ ) stimulate T-cytotoxic cells and NK cells to kill virally infected cells. B cells, antibodies and complement are also effective against certain viruses and toxinproducing micro-organisms.

\subsection{Infection}

Resistance to infection depends upon the general state of health of an individual as well as the 
individual's innate and adaptive immunological competence (Clarke 1984). Other factors which influence susceptibility include the dose and virulence of the infecting micro-organism (Clarke 1984).

Exercise affects several of the above variables. It can improve the individual's general state of health, but it may also modify exposure (for example, by causing mouth breathing, bypassing the nasal filter) [Niinimaa et al. 1980] and affect innate defences (for example, drying bronchial secretions and slowing ciliary action) [Rylander 1968]. Moderate training improves acquired immune function, but athletes who exercise strenuously may have a reduced immunological competence, particularly in situations where heavy training is combined with the stress of international competition (Fry et al. 1991a,b; 1992).

\section{Influence of Exercise on Immune Function}

Rigorous athletic training and sports participation modify various components of the innate and adaptive immune systems [Fry et al. 1991a,b, 1992; Keast \& Morton 1992), potentially increasing an athlete's immediate susceptibility to infectious illness (fig. 3). The psychological stress of athletic competition may further compromise host defences. However, there has been minimal research directly linking infection in athletes with altered immune parameters (Keast \& Morton 1992; Mackinnon et al. 1991; Nieman et al. 1990b; Verde et al. 1991, 1992a,b).

\subsection{Exercise and Innate Immunity}

The physical barrier of the skin is often damaged through trauma or maceration during sports participation, thus setting the stage for invasion by micro-organisms, particularly if there is an associated immunosuppression. Likewise, the normal filtration mechanism of the nose is bypassed and the inspiration of cold dry air thickens bronchial mucus and slows ciliary clearance of micro-organisms. Other alterations in innate immune parameters associated with very vigorous bouts of exer- cise include an acute increase of C-reactive protein levels (Fitzgerald 1988, 1991; Liesen \& Uhlenbruck 1992), a decrease in resting levels of serum complement (Berk et al. 1988; Nieman et al. 1989c; Smith et al. 1990a) and C-reactive protein (Dufaux et al. 1984), a reduction in neutrophil adherence and phagocytic activity (Gabriel et al. 1993; Lewicki et al. 1987; Smith et al. 1990b) and a postexercise suppression in NK cell activity (Berk et al. 1990; Mackinnon et al. 1986; Shinkai et al. 1992).

On a more long term basis, regular moderate exercise may enhance innate immunity (Crist et al. 1989; Keast \& Morton 1992; Nieman et al. 1990b). Nieman and associates (1990b) demonstrated that 15 weeks of regular moderate exercise (five 45minute sessions/week at $60 \%$ of the heart rate reserve) significantly increased NK cell activity in 18 females relative to 18 matched sedentary females. Moreover, the increased NK cell activity was linked to a reduction in the duration of symptoms associated with upper respiratory tract infections. More recently, Rhind et al. (1993) have found a close correlation between maximal oxygen intake and NK cell activity, with well trained individuals showing a much greater development of the 70 to $75 \mathrm{kDal}$ interleukin- $2 \beta$ receptor.

\subsection{Exercise and Adaptive Immunity}

Components of the adaptive immune response such as total lymphocyte counts, the ratio of helper to suppressor $\mathrm{T}$ cells, lymphocyte transformation and serum or secretory immunoglobulins (IgG and IgA) are all modified by acute bouts of strenuous exercise (Esperson et al. 1990; Green et al. 1981; Mackinnon 1992; Nieman \& Nehlsen-Cannarella 1992; Shinkai et al. 1992; Verde 1992a). However, a given bout of exercise may have a smaller acute impact on a trained than on an untrained individual (Verde et al. 1991, 1992a,c).

It has been suggested that the ratio of helper to suppressor $\mathrm{T}$ cells could identify athletes with an increased susceptibility to infection (Keast et al. 1988; Nash 1986). Both subpopulations of cells are important for immunoregulation, but a reduction in 


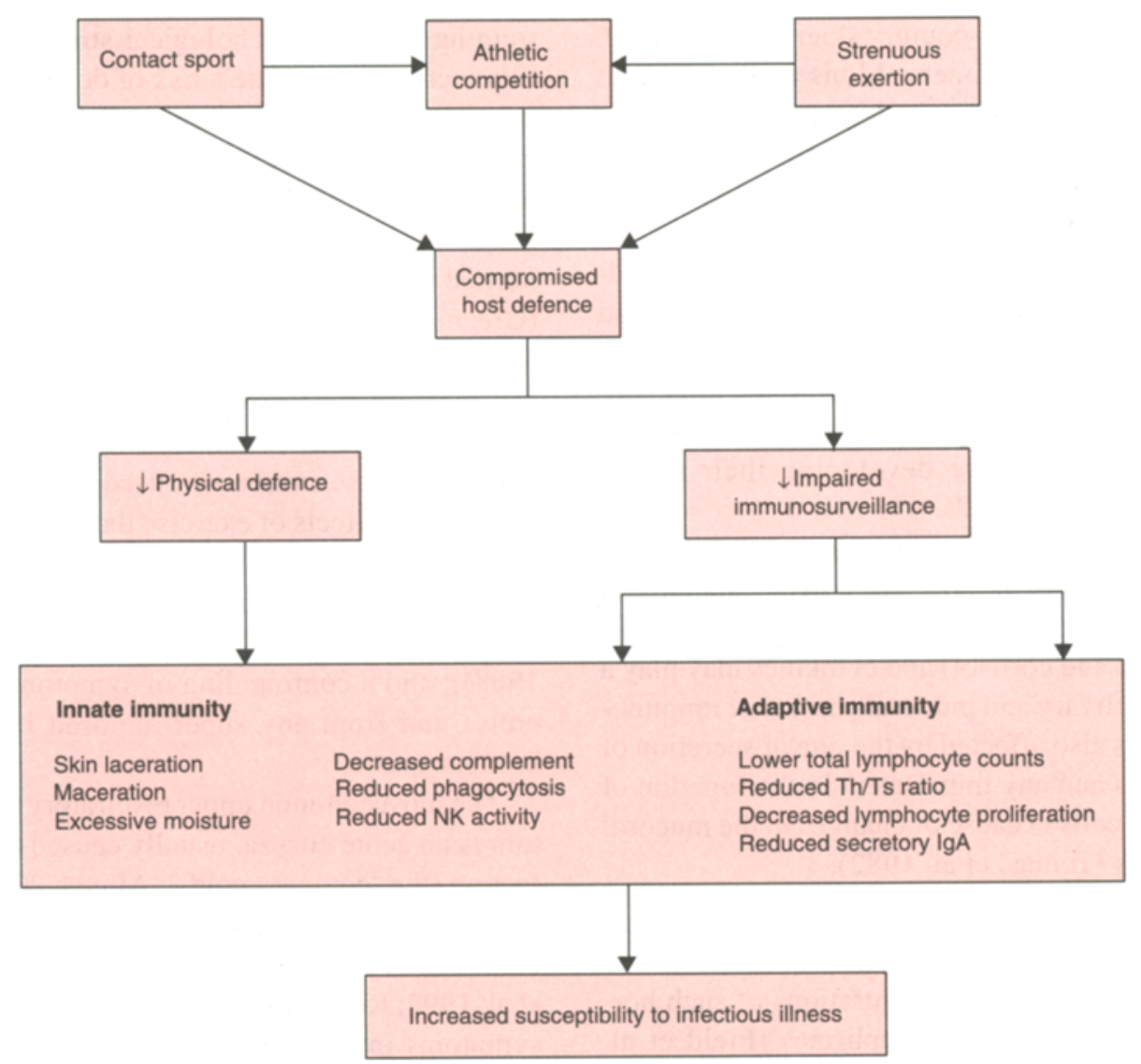

Fig. 3. Hypothetical relationship between athletic activity and infection. Abbreviations and symbols: IgA=immunoglobulin A; $\mathrm{NK}=$ natural killer; $\mathrm{Th}=\mathrm{T}$ helper cell; $\mathrm{Ts}=\mathrm{T}$ suppressor cell; $\downarrow=$ decreased.

the helper to suppressor $\mathrm{T}$ cell ratio below 1.0 to 1.5 is thought to indicate immunosuppression (Keast et al. 1988; Shephard et al. 1991). A reduced ratio has been observed following acute bouts of both strenuous submaximal exercise (Espersen et al. 1990; Verde et al. 1992a) and maximal exercise (Berk et al. 1986; Hack et al. 1993; Lewicki et al. 1988); however, reduced rates are not invariably observed in athletes who are showing other signs of overtraining (Fry et al. 1992).

Prolonged moderate intensity aerobic exercise (greater than $60 \%$ maximum oxygen uptake) and participation in a marathon run have both reduced in vitro lymphocyte proliferation response to external mitogens (Eskola et al. 1978; Hedfors et al.
1976; Shinkai et al. 1992; Verde et al. 1991, 1992a). Verde and colleagues $(1991,1992 \mathrm{c})$ reported that a deliberate $38 \%$ increase in the training volume of endurance runners, who already had a heavy conditioning schedule, reduced the cumulative lymphocyte proliferation rates immediately after an acute exercise bout. They noted that 2 of the 10 runners developed rhinoviral infections during the 3-week period when immune function was suppressed by the deliberate increase of training load.

Reductions in secretory immunoglobulins ( $\operatorname{Ig} \mathrm{A})$ have also been observed following prolonged exercise in treadmill runners (Hack et al. 1993; McDowell et al. 1992), in cyclists (MacKinnon \& Jenkins 1993; MacKinnon et al. 1986; Pedersen \& 
Tvede 1993), in cross-country skiers (Tomasi et al. 1982), in distance runners (Müns et al. 1989), in kayakers (Mackinnon et al. 1993) and in swimmers (Mackinnon et al. 1992), although repeated participation in basketball games increased resting salivary IgA (Thorp 1991). When athletes had low salivary immunoglobulin levels (IgA), susceptibility to upper respiratory infections was increased (Mackinnon et al. 1991; Order et al. 1989). Ninetytwo percent of athletes who developed upper respiratory infections had low secretory IgA concentrations 2 days before developing their illness (Mackinnon et al. 1992).

The primary mechanism responsible for many of these changes is still unknown. Changes in blood levels of both hormones (particularly catecholamines and cortisol) and cytokines may play a role. The salivary and mucosal content of immunoglobulins is also affected by the rate of secretion of these fluids and any impairment in the function of mucosal B cells because of changes in the mucosal membranes (Tomasi et al. 1982).

\subsection{Hormonal Effects}

Changes in plasma concentrations of such hormones as adrenaline (epinephrine) [Field et al. 1991; Kappel et al. 1991] and corticosterone (Pedersen et al. 1991; Tonnesen et al. 1987), induced by either exercise or psychologically stressful situations can have important immunomodulatory effects, altering the rate of transport of cells between lymph tissue and the blood stream, modulating the attachment of immunocompetent cells to the vascular endothelium, and reducing lymphocyte proliferation rates (Keast et al. 1988). Hydrocortisone can also interfere with the availability of immunoglobulin $(\mathrm{Fc})$ receptors on neutrophils, impairing the phagocytosis of IgG sensitised particles (Klempner \& Gallin 1978).

\section{Physical Activity and Infection}

3.1 Upper Respiratory Tract Infections

Coaches and athletic team physicians have used anecdotes and case studies to support their uncritical contention that a combination of excessive training and the psychological stress of competition increase an athlete's risk of developing an upper respiratory tract infection (Eichner 1993; Fitzgerald 1988; Heath et al. 1992; Jokl 1974; Keast \& Morton 1992; Keast et al. 1988; Legwold 1982; Linde 1987). In contrast, most athletes believe that normal physical training enhances their resistance (Green et al. 1981; Nieman et al. 1989a, 1990b), although they agree that intensive competition can increase susceptibility (Nieman et al. 1989a, 1990a). Problems in understanding the extent to which exercise increases susceptibility include: mechanical effects of exercise that modulate exposure to infectious micro-organisms [for instance, mouth-breathing (Niinimaa et al. 1980), drying of the mucosa and slowing of ciliary action (Rylander 1968)]; and a confounding of symptoms from exercise and from any super-imposed infection or bronchospasm.

The most common upper respiratory tract symptom is an acute coryza, usually caused by viral infection (the 'common cold'). Almost 200 different viruses have been implicated, but the rhinovirus or coronavirus is the most common pathogen (Heath et al. 1992; Roberts 1986; Thornton 1990). Typical symptoms include nasopharyngitis, nasal catarrh, cough and sore throat, with minimal fever and little or no systemic involvement. Other less common manifestations of upper respiratory tract infections include pharyngitis, croup, bacterial tracheitis or epiglotitis (Heath et al. 1992). In general, the risk of respiratory infection decreases to early adulthood (Heath et al. 1992), but increases again in older adults. Infants and young children have from 4 to 8 infectious episodes per year. In young adults the incidence ranges from 1 to 6 episodes per year (Badger et al. 1953; Fox et al. 1972; Gwaltney et al. 1966; Roberts 1986), common population averages being 1.5 to 2 episodes per year (Berglund \& Hemmingson 1990).

Studies which have examined the relationship between exercise and upper respiratory tract infections yield conflicting results (table II). Some authors have reported an increase in the incidence, duration and/or perceived severity of upper respi- 
ratory infections in physically active individuals (Douglas \& Hanssen 1978; Heath et al. 1991; Linde 1987; Linenger et al. 1993; Nieman et al. 1990a; Peters \& Bateman 1983; Seyfried et al. 1985). Other studies have reported either no difference (Lee et al. 1992; Österback \& Qvarnberg 1987) or even a reduction in the number and severity of such infections (Karper \& Boschen 1993; Nieman et al. 1989b; Nieman et al. 1990b; Schouten et al. 1988). Some research has suggested that top level athletes have a greater risk of upper respiratory tract infections compared with moderately active or sedentary control groups (Douglas \& Hanssen 1978; Linde 1987). Recreational athletes were also shown to have a predisposition to upper respiratory tract infection, particularly when participating in certain high risk activities such as swimming (Seyfried et al. 1985). Other studies have examined the impact of major competitions on the subsequent development of infections (Nieman et al. 1989b, 1990a; Peters \& Bateman 1983).

Douglas and Hanssen (1978) compared upper respiratory infections in university rowers with a sedentary group. The athletes reported symptoms more frequently and perceived their symptoms (stuffy nose, cough, malaise, laryngitis, aching joints and muscles, watery or burning eyes, nasal discharge and sore throat) as being more severe than those reported by the nonathletes.

Linde (1987) examined the incidence of respiratory tract infections in 42 elite orienteers ( 14 female, 28 male) and 41 nonathletes (14 female, 27 male), matched for age, sex and occupation. 2.5 episodes of upper respiratory tract infections were reported in orienteers compared with 1.7 episodes in nonorienteers $(\mathrm{p}<0.05)$. The symptoms also lasted longer in the orienteers than in the nonathletes (7.9 vs 6.4 days). However, no objective measures of immune function were made. Thus, it seems possible that the athletes (through their exercise) were more conscious of mild symptoms and as a result were more likely to seek medical care.

A prospective study of recreational swimmers and nonswimmers (Seyfried et al. 1985) found morbidity rates of 7.0 and $3.0 \%$ respectively. $\mathrm{Re}$ - spiratory ailments were most common in both groups, followed by gastrointestinal, eye, ear, skin and allergic symptoms. Overall, the swimmers reported more symptoms for each route of infection. Swimmers who swam with the head under water reported a substantially higher incidence of eye, ear and skin infections compared with those who swam with the head above water, but people who swam with the head above the water still reported more frequent respiratory, gastrointestinal and skin infections than nonswimmers.

Peters and Bateman (1983) interviewed 150 marathon runners and 150 age-matched sedentary individuals before and after the runners had participated in a $56 \mathrm{~km}$ ultramarathon. In the 2 weeks immediately following the race $33.3 \%$ of the runners reported symptoms such as runny nose, cough or sore throat, compared with $15.3 \%$ of nonrunners. The faster runners also seemed the most likely to report such complaints.

These results are supported by the findings of Nieman et al. (1990a). A questionnaire was used to examine the effects of exercise and perceived stress on the incidence of respiratory complaints (sore throat, cold or influenza) among almost 5000 participants in the 1987 Los Angeles marathon. The percentage of questionnaires returned was low $(46.9 \%)$, and was probably biased by those who had developed infections. However, the results showed that the most active runners had an increased likelihood of reporting such symptoms, both during training and following the marathon race. During training, the odds ratio was doubled in individuals who ran more than $97 \mathrm{~km} /$ week relative to those running less than $32 \mathrm{~km} /$ week. In the week following the race, respiratory symptoms were reported 5 times more frequently by participants than by runners who trained but did not compete in the event.

In contrast, participation in less strenuous and less competitive events did not alter the likelihood of respiratory complaints (Nieman et al. 1989b); the incidence of respiratory symptoms in 273 runners was similar before and after short road races $(5,10$ and $21 \mathrm{~km})$. 
Table II. Studies on exercise and upper respiratory tract infections (URI)

\begin{tabular}{|c|c|c|c|c|c|}
\hline Reference & Design & Participants & $\begin{array}{l}\text { Age } \\
\text { (years) }\end{array}$ & Evaluation methods & Findings \\
\hline \multicolumn{6}{|l|}{ Incidence studies } \\
\hline Strauss et al. (1988) & Prospective & 87 athletic team members & & Weekly interviews & $86 \%$ report 1 URI over 8 weeks \\
\hline $\begin{array}{l}\text { Budgett \& Fuller } \\
\text { (1989) }\end{array}$ & Retrospective & 69 oarsmen & $18-33$ & Questionnaire & URI in $59 \%$ over 52 weeks \\
\hline $\begin{array}{l}\text { Berglund \& } \\
\text { Hemmingson (1990) }\end{array}$ & Prospective & $\begin{array}{l}121 \mathrm{M}, 53 \mathrm{~F} \text { cross-country } \\
\text { skiers }\end{array}$ & $16-21$ & Diary technique & $\begin{array}{l}\text { URI accounts for } 92.3 \% \text { of all } \\
\text { illness }\end{array}$ \\
\hline \multicolumn{6}{|c|}{ Risk of URI increased } \\
\hline $\begin{array}{l}\text { Douglas \& Hanson } \\
(1978)\end{array}$ & Prospective & 61 rowers, 126 cadets & $18-26$ & $\begin{array}{l}\text { Validated symptom } \\
\text { checklist }\end{array}$ & $\begin{array}{l}\uparrow \text { frequency \& severity of URI in } \\
\text { athletes }\end{array}$ \\
\hline $\begin{array}{l}\text { Peters \& Bateman } \\
\text { (1983) }\end{array}$ & Prospective $^{a}$ & $\begin{array}{l}150 \text { runners vs } \\
\text { nonrunners }\end{array}$ & $18-65$ & $\begin{array}{l}\text { Questionnaire, } \\
\text { interview }\end{array}$ & $\begin{array}{l}\uparrow \text { URl in athletes, seen in faster } \\
\text { runners }\end{array}$ \\
\hline Seyfried et al. (1985) & Prospectivea & $\begin{array}{l}8000 \text { swimmers vs } \\
\text { nonswimmers }\end{array}$ & $0-70$ & $\begin{array}{l}\text { Questionnaire, } \\
\text { telephone }\end{array}$ & $\uparrow$ URI in swimmers \\
\hline Linde (1987) & Prospective & 42 orienteers, 41 controls & $19-34$ & Diary & $\begin{array}{l}\uparrow \text { URI incidence and duration in } \\
\text { orienteers }\end{array}$ \\
\hline $\begin{array}{l}\text { Nieman et al. } \\
(1989 a)\end{array}$ & Retrospective & $9 \mathrm{M}, 1 \mathrm{~F}$ marathon runners & $27-44$ & Questionnaire & $\begin{array}{l}7 \text { perceive } \uparrow \text { risk of URI } \\
\text { following competition }\end{array}$ \\
\hline $\begin{array}{l}\text { Nieman et al. } \\
(1990 \mathrm{a})\end{array}$ & $\begin{array}{l}\text { Retrospective } \\
+ \text { prospective }^{\mathrm{a}}\end{array}$ & $\begin{array}{l}2311 \text { runners vs } \\
\text { nonrunners }\end{array}$ & $34-39$ & Questionnaire & $\begin{array}{l}2 \times \uparrow \text { URI with training, } 6 \times \uparrow \\
\text { post-race }\end{array}$ \\
\hline Heath et al. (1991) & Prospective & $447 \mathrm{M}, 83 \mathrm{~F}$ runners & $13-75$ & Questionnaire & $\uparrow$ URI with $\uparrow$ running mileage \\
\hline $\begin{array}{l}\text { Linenger et al. } \\
\text { (1993) }\end{array}$ & Prospective & $\begin{array}{l}482 \text { trainee-months } \\
\text { (special warfare trainees) }\end{array}$ & $18-31$ & Physician diagnosed & High incidence of URI \\
\hline \multicolumn{6}{|l|}{ Risk unchanged } \\
\hline $\begin{array}{l}\text { Österback \& } \\
\text { Qvamberg (1987) }\end{array}$ & Prospective & $\begin{array}{l}62 \text { sports participants vs } \\
75 \text { controls }\end{array}$ & $11-14$ & Interview & $\leftrightarrow$ in URI sports vs controls \\
\hline $\begin{array}{l}\text { Schouten et al. } \\
\text { (1988) }\end{array}$ & Retrospective & $92 \mathrm{M}, 107 \mathrm{~F}$ active people & $20-23$ & Questionnaire & $\begin{array}{l}\text { URI not related to fitness or } \\
\text { activity level }\end{array}$ \\
\hline $\begin{array}{l}\text { Nieman et al. } \\
(1989 b)\end{array}$ & Retrospective & $183 \mathrm{M}, 90 \mathrm{~F}$ runners & $31-38$ & Questionnaire & $\leftrightarrow$ pre- vs post-race \\
\hline Lee et al. (1992) & Prospective & 96 Air Force cadets & $?$ & $\begin{array}{l}\text { Medical charts, } \\
\text { symptom checklist }\end{array}$ & $\begin{array}{l}\text { Immune function depressed but } \\
\text { no increase in infections }\end{array}$ \\
\hline \multicolumn{6}{|l|}{ Risk reduced } \\
\hline Green et al. (1981) & Retrospective & $20 \mathrm{M}$ marathon runners & $23-46$ & Questionnaire & 9 perceive risk of URI $\downarrow$ \\
\hline $\begin{array}{l}\text { Schouten et al. } \\
(1988)\end{array}$ & Retrospective & $92 \mathrm{M}, 107 \mathrm{~F}$ active people & $20-23$ & Questionnaire & $\begin{array}{l}\downarrow \text { URI symptoms in active } \\
\text { females }\end{array}$ \\
\hline $\begin{array}{l}\text { Nieman et al. } \\
(1989 a)\end{array}$ & Retrospective & 9M, if marathon runners & $27-44$ & Questionnaire & 9 perceive risk of URI $\downarrow$ \\
\hline $\begin{array}{l}\text { Nieman et al. } \\
(1990 \mathrm{~b})\end{array}$ & Prospective & $36 \mathrm{~F}$ & $25-45$ & Log books & $\begin{array}{l}\text { Physical conditioning } \downarrow \text { URI } \\
\text { symptom duration }\end{array}$ \\
\hline $\begin{array}{l}\text { Karper \& Boschen } \\
\text { (1993) }\end{array}$ & Prospective & $16(10 F, 6 M)$ & $60-72$ & Log books & $\begin{array}{l}\text { Physical conditioning reduced } \\
\text { infections relative to initial } \\
\text { values (retrospective) }\end{array}$ \\
\hline
\end{tabular}

a Epidemiological study.

Abbreviations and symbols: $F=$ female, $M=$ male, $\uparrow=$ increase, $\downarrow=$ decrease, $\leftrightarrow=$ no change; ? = unknown. 
A large proportion of athletes (e.g cross-country skiers, gymnasts, oarsmen, swimmers and wrestlers) suffer from upper respiratory tract infections, but no more frequently than would be anticipated in sedentary people (Berglund \& Hemmingson 1990; Budgett \& Fuller 1989; Strauss et al. 1988).

Strauss and colleagues (1988) interviewed men's intercollegiate athletic teams (wrestling, swimming and gymnastics) over an 8-week competitive season. Of 87 athletes, 75 (86\%) developed at least 1 upper respiratory infection. Moreover, the incidence of illness was highest during the first 5 weeks of training. Such figures certainly exceed the usual rates for the general population of 1.5 to 2.0 episodes per year (Berglund \& Hemmingson 1990), although observations were collected during the winter months of January and February (when respiratory infections are somewhat more frequent). Berglund and Hemmingson (1990) had 174 individuals maintain a 1-year diary in which they noted their reasons for absence from training. The main reason cited was an upper respiratory tract infection; however, the frequency reported in their study ( 1.5 incidents/year) was no greater than in the general population. Other reasons for halting training included skin infections and gastroenteritis. Budgett and Fuller (1989) used a retrospective study to investigate illnesses in 30 international oarsmen; $83 \%$ of them reported upper respiratory tract infections, with an incidence of 1.4 episodes per year.

The relationship between the weekly walking/running distance and the risk of upper respiratory infections is best explained by a ' $\mathrm{J}$ ' shaped model (Heath et al. 1992; Nieman \& NehlsenCannarella 1992). The model is descriptive rather than quantitative, implying that excessive training or a single very severe bout of exercise increases the risk of upper respiratory tract infections, whereas habitual moderate exercise lowers the risk relative to a sedentary lifestyle. Nieman et al. (1990a) found that the distance runner's risk of illness increased when training exceeded $97 \mathrm{~km} /$ week. Heath et al. (1991) analysed upper respiratory tract infections in 530 runners. Risk factors included running more than $776 \mathrm{~km} /$ year $(15 \mathrm{~km} /$ week), living alone and a low body mass index. It was suggested (although without strong evidence) that social support protected against infection and that the stress of living alone predisposed to the development of illness. In support of the adverse effect of a low body mass index, recent biochemical studies suggest that the reserves of amino acid in muscle tissue may be quite important to immune function (Parry-Billings et al. 1990, 1992).

One study of heavy military training (Linenger et al. 1993) noted a high incidence of both musculoskeletal injuries and respiratory infections. A second report (Lee et al. 1992) demonstrated a reduction of in vitro immune responsiveness during basic cadet training, but in this study there was no associated increase in symptomatology or illness.

Schouten et al. (1988) reported a negative correlation between the incidence of upper respiratory tract symptoms and a moderate level of sports participation in female study participants. Nieman et al. (1990b) also demonstrated that 15 weeks of physical conditioning ( 45 minutes, 5 days/week) at a moderate intensity ( $60 \%$ of the heart rate reserve) helped to reduce the duration of symptoms of upper respiratory tract infections in a group of women 25 to 45 years of age. Karper and Boschen (1993), likewise, trained 16 seniors 3 times a week for 9 to 12 months; 12 of the 14 who completed the programme showed a reduced incidence of respiratory symptom relative to their pre-programme experience.

Evidence of the relationship between other types of sports activities (Österback \& Qvarnberg 1987; Schouten et al. 1988) and the incidence of upper respiratory tract infections is inconsistent, and in some instances the ' $\mathrm{J}$ '-shaped model does not appear to apply. For example, Schouten et al. (1988) found no relationship between either the incidence or the duration of upper respiratory tract infections and the volume of habitual physical activity or the resulting maximal oxygen consumption. Schouten et al. (1988) quantified the weekly dose of physical activity as the product of duration ( $\mathrm{min} /$ week) and energy expenditure (METs/week), 
making the study difficult to compare with other investigations that have specified running distances; however, the exercise levels considered (> $700 \mathrm{MET} \cdot \mathrm{min} /$ week) seem less than in some studies where adverse effects were observed.

Österback and Qvarnberg (1987) conducted a prospective study of respiratory infections in children who participated in extracurricular physical activity (gymnasts, swimmers and ice hockey) 4 times per week. The incidence of infection was the same as in other elementary school children and music students who participated only 2.7 times per week (intensity and duration not specified). However, no record was made of spontaneous leisure activity, and it seems likely that the total dose of exercise even in the more active group was less than in some studies reporting adverse effects.

Overall, these studies suggest that elite and endurance athletes may be more susceptible to upper respiratory tract infections than the general population during periods of excessive training and/or intense competitive stress. In contrast, recreational athletes do not appear more susceptible to upper respiratory infections than the general population and some groups have even shown an enhanced resistance to infectious illness. Further research is required to determine the type, intensity and duration of exercise most likely to be immunoenhancing. It would also be helpful to obtain data on such potential modifiers of the immune response as lean tissue mass, nitrogen balance and tissue injuries. Finally, it seems desirable to examine possible protection of immune function from the use of prostaglandin inhibitors such as indomethacin (Pedersen et al. 1990; Shephard \& Shek 1993).

\subsection{Cutaneous Infections}

Athletic activity, particularly contact sports, is associated with an increased risk of skin infections (table III). Bacterial, viral and fungal infections may develop through direct contact with others and may be facilitated by excessive exposure to ultraviolet radiation, sweating and skin friction (Conklin 1990; Sharp et al. 1988). Sweating macerates the skin, softening the stratum corneum and im- pairing the body's natural defence against infection (Basler 1983). Trauma also breaches the physical barrier of the skin. A moist and softened skin facilitates both adherence and skin penetration by micro-organisms (Cole \& Silverberg 1986). Athletic clothing and footwear offer a warm, moist environment that is conducive to the growth of both bacteria and fungi and problems are particularly likely if athletic clothing is not washed frequently (Allen \& King 1978; Basler 1983; Duncan et al. 1969).

\subsubsection{Bacterial Infections}

Sports activities contribute to the development of such bacterial infections as impetigo, furunculosis and folliculitis (Basler 1983; Conklin 1990). Impetigo is common in wrestlers and rugby players (Becker et al. 1988; Dorman 1981; Glezen et al. 1972; Ludlam \& Cookson 1984). It is usually caused by Streptococcus pyogenes, although there may be secondary Staphylococcus aureus infection (Bergfeld 1984; Conklin 1990). Otitis externa is seen frequently in swimmers (Hicks 1977; Hoadly \& Knight 1975).

Furuncles and abscesses usually occur because of localised $S$. aureus infections (Bergfeld 1984). Such lesions are common in basketball players (Sosin et al. 1989), football players (Bartlett et al. 1982; Sosin et al. 1989) and in river rafters (Decker et al. 1986). A persistent superficial infection of the hair follicles, termed 'acne mechanica' (Basler 1983; Farber et al. 1977), commonly occur in athletes, such as football and hockey players who need to wear heavy protective clothing.

\subsubsection{Viral Infections}

Viral infections of the skin in sports participants include herpes simplex, molluscum contagiosum, and verrucae vulgaris (Basler 1983). The most frequently reported skin infection is herpes simplex type I virus (HSV-1). The incubation period for $\mathrm{HSV}-1$ ranges from a few days to 2 weeks (Nelson 1992). Prodomal symptoms such as a burning, stinging or itching of the skin or an erythema may precede infection by a few hours. The condition is characterised by an extensive vesiculopustular eruption, with an underlying erythema (Nelson 
Table III. Sports activities and skin infections

\begin{tabular}{|c|c|c|c|c|}
\hline Sport & Disease & Micro-organism & Type of infection & Reference \\
\hline Basketball & Bacterial & Staphylococcus aureus & Furunculosis & Sosin et al. (1989) \\
\hline Boxing & Viral & Smallpox & Vaccinia & Hanssen (1948) \\
\hline Figure skating & Not identified & & 'Skin infection' & Smith \& Micheli (1982) \\
\hline \multirow[t]{3}{*}{ Football } & Bacterial & Streptococcus pyoderma & Scrum strep/pox (impetigo) & Glezen et al. (1972) \\
\hline & & $\begin{array}{l}\text { Staphylococcus albus, } \\
\text { Corynebacterium }\end{array}$ & Acne mechanica & Farber et al. (1977) \\
\hline & & Staphylococcus aureus & Furunculosis & $\begin{array}{l}\text { Bartlett et al. (1982); Sosin et al. } \\
\text { (1989) }\end{array}$ \\
\hline River rafting & Bacterial & Staphylococcus aureus & $\begin{array}{l}\text { Furunculosis, abcesses, } \\
\text { cellulitis }\end{array}$ & Decker et al. (1986) \\
\hline \multirow[t]{4}{*}{ Rugby/soccer } & Viral & Herpes simplex virus I & $\begin{array}{l}\text { Scrum pox, herpes } \\
\text { rugbeiorum, herpes } \\
\text { venaturum }\end{array}$ & $\begin{array}{l}\text { Maré et al. (1978); Shute (1979); } \\
\text { White et al. (1984); Verbov \& } \\
\text { Lowe (1974) }\end{array}$ \\
\hline & Bacterial & Group A streptococci & Scrum strep (impetigo) & Dorman (1981) \\
\hline & & Streptococcus pyogenes & Scrum kidney (impetigo) & Ludlam \& Cookson (1984) \\
\hline & Fungus/bacterial & & Tinea pedis & Gentles et al. (1975) \\
\hline Skiing & Viral & Herpes simpex virus I & Herpes labialis & $\begin{array}{l}\text { Mills et al. (1987); Spruance et } \\
\text { al. (1988) }\end{array}$ \\
\hline \multirow[t]{4}{*}{ Swimming } & Viral & Molluscum contagiosum & & $\begin{array}{l}\text { Postlewaite \& Watt (1967); } \\
\text { Niizeki et al. (1984) }\end{array}$ \\
\hline & Bacterial & Herpes simplex virus I & Herpes & Hicks (1977) \\
\hline & & Pseudomonas aeruginosa & Otitis externa & $\begin{array}{l}\text { Hicks (1977); Hoadly \& Knight } \\
\text { (1975) }\end{array}$ \\
\hline & Fungus/bacterial & $\begin{array}{l}\text { Trichophyton, Candida } \\
\text { albicans }\end{array}$ & Tinea pedis & $\begin{array}{l}\text { Gentles et al. (1974); Hicks } \\
\text { (1977) }\end{array}$ \\
\hline \multirow[t]{3}{*}{ Wrestling } & Viral & Herpes simplex I virus & Herpes gladiatorum & $\begin{array}{l}\text { Becker et al. (1988); Belongia et } \\
\text { al. (1991); Duda (1989); Dyke et } \\
\text { al. (1965); Nelson (1992); Porter } \\
\text { \& Baughmann (1965); Selling \& } \\
\text { Kibrick (1964); Wheeler \& } \\
\text { Cabaniss (1965); White (1992) }\end{array}$ \\
\hline & & Molluscum contagiosum & & Becker et al. (1988) \\
\hline & Bacterial & Streptococcus pyogenes & Impetigo & \\
\hline
\end{tabular}

1992; Porter \& Baughmann 1965). 25\% of athletes may experience systemic effects, including fever, myalgia, lethargy, headache, sore throat, and regional lymphadenopathy (Nelson 1992).

HSV infection has been observed among athletes involved in contact sports and recreational athletes who have had prolonged exposure to ultraviolet radiation. Wrestlers affected often refer to it as 'herpes gladiatorum' (Becker et al. 1988; Be- longia et al. 1991; Duda 1989; Dyke et al. 1965; Nelson 1992; Porter \& Baughmann 1965; Selling \& Kibrick 1964; Wheeler \& Cabaniss 1965; White 1992). In rugby or soccer, it is has been termed 'herpes rugbeiorum', 'herpes venaturum' or 'scrum pox' (Maré et al. 1978; Shute et al. 1979; Verbov $\&$ Lowe 1974). Athletes in contact sports are at particular risk of infection because of skin abrasions during direct skin contact with infected indi- 
viduals. The most common sites of infection are the head, neck, upper extremities and trunk.

Infection of the lips ('herpes labialis') is common in skiers (Mills et al. 1987; Spruance et al. 1988). Excessive exposure to ultraviolet radiation and cold are triggering factors for development or reactivation of herpes labialis (Mills et al. 1987). The stress of high altitude exposure or increased physical activity may also provoke a reaction (Mills et al. 1987). The average time between first exposure to the sun and reactivation of the skin condition is 3.5 days (Mills et al. 1987). It is believed that sun-induced skin irritation stimulates nerve fibres originating in the trigeminal ganglion, and that this reactivates the virus (Mills et al. 1987). Frequent exposure to the virus may increase epidermal susceptibility (Mills et al. 1987).

Molluscum contagiosum infection is common in swimmers. It is acquired through water contact in pools, pool decks and changing areas (Niizeki et al. 1984; Postlewaite \& Watt 1967), but may also be transmitted through skin contact and trauma (Becker et al. 1988; Roberts 1986).

Verrucae vulgaris is not particularly frequent in athletes (Basler 1983; Conklin 1990; Freeman \& Bergfeld 1977; Houston \& Knox 1977; Resnik et al. 1977). Plantar warts can be transmitted on swimming pool decks and floors of shower areas, whereas hand warts can be transmitted by the handling of gymnastic equipment (Basler 1983; Conklin 1990). Athletes may have an increased risk of developing warts because of the macerating effect of water or sweat on the skin (Basler 1983). The resulting discomfort and pain can impair performance (Houston \& Knox 1977).

\subsubsection{Fungal Infections}

Tinea pedis is transmitted through swimming pools and the floors of gymnasia and locker rooms (Gentles et al. 1974; Hicks 1977). Organisms potentially involved include Trichophyton rubrum, Trichophyton mentagrophytes and Candida albicans (Resnik et al. 1977). There may also be a mixed fungal and bacterial infection (Conklin 1990). Small vesicles between the toes, sides of the feet and the soles may progress to an advanced scaling dermatitis with a reddened border (Bergfeld 1984). Analogous infections include tinea cruris ('jock itch') and monilial intertrigo (Houston and Knox 1977).

\subsection{Other Infections}

Pools, rivers, lakes and sea water may contain a mixture of avirulent, virulent, and opportunistic pathogenic micro-organisms (Joseph et al. 1991) which can lead to outbreaks of gastrointestinal illness (nausea, vomiting, stomach cramps, and diarrhoea) amongst swimmers. Infection can occur in individuals following ingestion of contaminated water while swimming (Rosenberg et al. 1976). Contamination of swimming pool water and subsequent disease transmission may be the result of either a malfunction in the pool chlorination system or a faecal accident (D'Alessio et al. 1981; D'Angelo et al. 1979; Harter et al. 1984; Kappus et al. 1982; Lenaway et al. 1989; Porter et al. 1988; Turner et al. 1987). Inefficient disposal of sewage and waste waters has also resulted in elevated counts of infectious virus particles (Norwalk agent), bacteria (Enterococci) as well as parasites (Shigellosis sonnei) in fresh and salt water (Balarajan et al. 1991; Baron et al. 1982b; Joseph et al. 1991; Makintubee et al. 1987; Rosenberg et al. 1976; Von Schirnding 1989).

The severity of pneumonia, hepatitis and poliomyelitis (table IV) are all augmented if exercise is performed during the infectious stage of the disease (Berg et al. 1971; Cowles 1918; Hargreaves 1948; Krinkler \& Zilberg 1966; Russell 1947, 1949). One outbreak of hepatitis $A$ in members of a football team (Morse et al. 1972) was traced to use of a contaminated water source near a playing field; however, exercise-related immunosuppression may have also made the team more susceptible to the infection. Baron et al. (1982a) reported that athletes have an increased vulnerability to an enterovirus, with some athletes developing aseptic meningitis.

There have been suggestions that human immunodeficiency virus (HIV) infection could be spread by physical contact between 2 wounded athletes, 
Table IV. Physical activity and other infections

\begin{tabular}{|c|c|c|}
\hline Infection & Observation & Reference \\
\hline \multirow[t]{6}{*}{ Viral hepatitis } & Vigorous physical activity associated with fulminating hepatitis & Krinkler \& Zilberg (1966) \\
\hline & Unusual outbreak of hepatitis A observed in football team members & $\begin{array}{l}\text { Morse et al. (1972); Friedman } \\
\text { et al. (1985) }\end{array}$ \\
\hline & Case study of a football player & Bowman (1976) \\
\hline & Epidemic of serum hepatitis in cross-country track runners & Berg et al. (1971) \\
\hline & $\begin{array}{l}\text { Physical activity in early convalescence did not cause relapse or prolong } \\
\text { recovery }\end{array}$ & Edlund (1971) \\
\hline & $\begin{array}{l}\text { Light exercise (e.g. walking) was not harmful in the acute phase of } \\
\text { hepatitis }\end{array}$ & $\begin{array}{l}\text { Chalmers et al. (1955); } \\
\text { Nefzger \& Chalmers (1963) }\end{array}$ \\
\hline $\begin{array}{l}\text { Aseptic meningitis (Entero- } \\
\text { viral illness) }\end{array}$ & $70 \%$ of football team members affected $v s 10 \%$ of nonteam members & Baron et al. (1982a) \\
\hline \multirow[t]{3}{*}{$\begin{array}{l}\text { Human immunodeficiency } \\
\text { virus (HIV) }\end{array}$} & $\begin{array}{l}\text { Acquired immune deficiency syndrome in a bodybuilder may have been } \\
\text { the result of sharing of infected needles while injecting anabolic steroids }\end{array}$ & Sklarek et al. (1984) \\
\hline & Report of transmission of HIV during a football match & Torre et al. (1990) \\
\hline & $\begin{array}{l}\text { Aerobic exercise training in previously sedentary seropositive males } \\
\text { attenuate acute stress related decrements in immune function. Training } \\
\text { increased helper-T cell concentration and improve psychological status }\end{array}$ & $\begin{array}{l}\text { LaPerriere et al. }(1990,1991) \\
\text { Schlenzig et al. }(1990)\end{array}$ \\
\hline \multirow{2}{*}{$\begin{array}{l}\text { Mononucleosis (Epstein } \\
\text { Barr virus) }\end{array}$} & Noncontact physical activity can safely be initiated after the febrile stage & Welch \& Wheeler (1986) \\
\hline & $\begin{array}{l}\text { Contact sport can be resumed } 1 \text { month after illness provided } \\
\text { splenomegaly is not present }\end{array}$ & Eichner (1987) \\
\hline Pneumonia & $\begin{array}{l}\text { Respiratory infection progressed to pneumonia after intense exercise } \\
\text { and physical sport }\end{array}$ & Cowles (1918) \\
\hline \multirow[t]{2}{*}{ Poliomyelitis } & $\begin{array}{l}\text { Increase in incidence and severity of paralysis associated with physical } \\
\text { activity. Paralysis located in active body regions }\end{array}$ & $\begin{array}{l}\text { Russell (1947); Hargreaves } \\
\text { (1948); Russell (1949); } \\
\text { Horstmann (1950) }\end{array}$ \\
\hline & Poliomyelitis infected members of football and soccer teams & Weinstein (1973) \\
\hline
\end{tabular}

but the World Health Organisation has noted that this is an extremely remote risk (Sharp et al. 1988). Only 2 instances of transmission between athletes have been described to date, although it is possible that such incidents may be underreported. Torre et al. (1990) reported transmission of HIV between 2 players as a result of a collision during a football match. Sklarek et al. (1984) suggested that the sharing of needles for anabolic steroid injections may have led to HIV infection and acquired immune deficiency syndrome (AIDS) in at least one bodybuilder.

In a recent review, Calabrese and LaPerriere (1993) summarised the current state of knowledge regarding the effects of exercise on the immune system of individuals infected with HIV. Regular moderate physical conditioning can improve the quality of life of HIV infected individuals (Macarthur et al. 1993) as well as decrease HIV disease progression, regardless of their stage of infection [asymptornatic HIV infected, AIDS related complex (ARC), AIDS] (Calabrese \& LaPerriere 1993). Also, in individuals who have become seropositive, regular moderate physical activity can not only improve physical fitness (Macarthur et al. 1993; Rigsby et al. 1992; Spence et al, 1990), but also attenuate decrements in immune function (LaPerriere et al. 1990, 1991) with increases in helper T cell counts (LaPerriere et al. 1990, 1991; Schlenzig et al. 1990). 


\section{Exercising Before and During an Acute Infectious Illness}

\subsection{Morbidity and Mortality}

Interactions between exercise and infection are complex and multidimensional (Ilbäck et al. 1989). The effect of exercise on the progression of a disease depends upon the type of infection, the quantity and quality of the exercise that is undertaken and the timing of exercise relative to the course of the infection. In general, moderate exercise before an infection may enhance resistance, whereas exhaustive exercise during the infectious stage of an illness may be detrimental (Cannon \& Kluger 1984). During convalescence, moderate exercise does not seem to have any adverse effects (Chalmers et al. 1955; Nefzger \& Chalmers 1963; Welch \& Wheeler 1986).

\subsubsection{Bacterial Infections}

Early researchers initially hypothesised that fatigue might increase susceptibility to infectious disease (Bailey 1925; Nicholls \& Spaeth 1922; Oppenheimer \& Spaeth 1922). Several animal species (guinea pigs, rabbits, rats) were exercised to fatigue before experimental infection with type I pneumococcus. Such studies suggested that exhausting exercise before inoculation increased the animal's resistance to infection. More recently, studies on mice infected with Salmonella typhimurium or Francisella tularensis have also demonstrated that physical conditioning prior to infection augments the production of antibodies (Liu \& Wang 1987). Moreover, survival rates have remained the same (Ilbäck et al. 1984) or have even been enhanced by previous exercise (Cannon \& Kluger 1984).

\subsubsection{Parasitic and Viral Infections}

In contrast to the findings for bacterial infections, exercise before and during a parasitic or viral infection increases morbidity and mortality (Elson \& Abelmann 1965; Ilbäck et al. 1984). Individuals who exercise during a viral illness can develop myocarditis, with some increase in the risk for sudden death (Drory et al. 1991; Phillips et al. 1986), although a fatal viral myocarditis is a relatively rare occurrence. Animal models have examined the effects of forced swimming on the virulence of Coxsackie B3 virus (Cabinian et al. 1990; Gatmaitan et al. 1970; Kiel et al. 1989; Lerner \& Wilson 1973; Reyes \& Lerner 1976; Reyes et al. 1981; Tilles et al. 1964). Mice who were exercised demonstrated extensive myocardial inflammation and necrosis, with an increased mortality. However, forced treadmill exercise in mice increased morbidity but had no effect on mortality (Ilbäck et al. 1989).

Studies involving humans, monkeys and mice have demonstrated that acute exercise during infection with anterior poliomyelitis or hepatitis can augment the severity of the disease (Hargreaves 1948; Horstmann 1950; Krinkler \& Zilberg 1966; Levinson et al. 1945; Russell 1947, 1949; Rosenbaum \& Harford 1953; Weinstein 1973). In a study of 411 patients from 3 epidemics of anterior poliomyelitis, Horstmann (1950) noted that when physical activity was undertaken at the onset of the illness, it resulted in a significant increase in the severity of disease process. More of those who escaped eventual paralysis had bed rest during the first 3 days of the infection. Likewise, Krinkler and Zilberg (1966) reported that 5 patients with fulminant hepatitis had all undertaken vigorous physical activity during the early stages of the disease.

The finding that the course of bacterial infections is less influenced by exercise than the course of viral or parasitic infections may be explained by the differing immune responses that they elicit. Bacterial infections involve predominately phagocytic cells, whereas the immune response to viral and parasitic infections is predominately $\mathrm{T}$ cell $\mathrm{me}$ diated (Thong 1986). This suggests that heavy exercise adversely affects immune function primarily through $\mathrm{T}$ cell mediated mechanisms; a deterioration in cell-mediated immunity may well explain the greater virulence of infections in animals that are exercised during infection (Cabinian et al. 1990; Kiel et al. 1989). 


\subsection{Decrements in Physical Performance}

Animal studies have demonstrated impaired physical performance, as reflected by a reduced time to exhaustion, during various types of acute infection (Friman et al. 1982, 1991; Ilbäck et al. 1983, 1991). One of the first studies reporting a decrement of physical performance during an infection was on patients with pulmonary tuberculosis (Dorman \& Friedlander 1942); a decrement in physical ability was suggested as an early indicator of tuberculosis infection, although it is possible that tuberculous disease sufficient to limit performance would be regarded as relatively advanced by modern standards. In humans, aerobic power, isometric and isokinetic strength are all adversely affected during acute infectious illnesses (Daniels 1985; Friman 1977, 1985). Athletic performance is also commonly impaired during an infectious illness, but the effects are transitory, and the customary level of performance is quickly restored after convalescence (Friman 1977).

Various factors contribute to these decrements in performance. Infection is a physiological stressor. It disturbs resting homeostasis and induces an inflammatory response (Cularke 1984). Metabolic shifts occur during the early phase of infection (for example, the core temperature, heart rate and oxygen consumption of the host are all increased) [11bäck et al. 1991]. Later, during the post-infective phase, there may be changes in the activities of performance-related enzymes in the skeletal muscle and myocardium (Friman et al. 1985; Ilbäck et al. 1991). In addition, an athlete may perceive the infection as imposing a handicap, increasing their psychological stress and thus impairing performance (Clarke 1984; Friman et al. 1985). Performance decrements have also been observed to occur in association with sleep deprivation and shifts in time zones (Shephard 1984). Circadian rhythms may contribute to variations in performance dependent upon reaction speed and muscle force (Shephard 1984).

\section{Clinical Implications}

This review has illustrated that athletes are not always resistant to infectious illness and that in some circumstances they may even have an increased susceptibility to upper respiratory tract and skin infections. Preventive measures should be instituted to reduce the risk of infection including: minimising exposures to pathogens, monitoring of the training plan, maintaining an adequate diet and limiting exposures to stressors (Shephard \& Shek 1993).

To minimise exposure to infection, athletes should avoid contact with individuals (especially small children) who have symptoms or signs of an infectious illness. Any team members who develop symptoms should be isolated from their peers as soon as is practicable. Since viruses are often transmitted by hand contact, the hands should be washed regularly (especially before eating) and any rubbing of the eyes or of the nose should be avoided (Shephard \& Shek 1993).

As overtraining and the stress of competition increase susceptibility to infection, athletes should avoid excessive conditioning and ensure that other life stresses are minimised (Fry et al. 1992; Heath et al. 1992). Sufficient recovery time should be allotted between strenuous practices and competitive events, the diet should be well balanced and sufficient to maintain a positive nitrogen balance, and adequate sleep should be encouraged (Heath et al. 1992), particularly if circadian rhythms have been disturbed by travel. Treatment modalities such as sauna, massage, hydrotherapy and physiotherapy may help to reduce the level of stress (Shephard \& Shek 1993). Other possible measures include counselling, progressive muscle relation, distraction or visual imagery. Muscular immunoglobulin injections may reduce the incidence, duration and severity of upper respiratory tract illness in athletes (Billigmann 1991; Nieman \& Nehlsen-Cannarella 1991; Weiss 1993). The inoculation of viruses endemic to the area where an athlete will compete may also be useful (Shephard \& Shek 1993).

Athletes who have developed a minor upper respiratory tract infection without systemic involve- 
ment may continue to exercise during the infection (Roberts 1986; Simon 1987). Decongestants should be taken during the day, with addition of an antihistamine at night (Thornton 1990), although care must be shown to avoid conflict with antidoping rules as competition is approached. Use of most aerosol $\beta_{2}$-agonists [salbutamol (albuterol), terbutaline, orciprenaline, rimiterol and bitolterol], with the exception of fenoterol, are permitted during international competition (Morton \& Fitch 1990). Other acceptable medications include: sodium cromoglycate, nedocromil sodium, theophylline, aerosol ipratropium bromide and beclomethasone (Morton \& Fitch 1990).

In view of the occasional findings of cardiomyopathy, the training intensity should be reduced if there are symptoms or signs of systemic involvement (such as fever, myalgia, fatigue or lymphadenopathy). In such individuals, 2 to 4 weeks should be allowed for recovery before strenuous exercise is resumed. Eichner (1993) recently provided a 'neck check' for anyone wanting to exercise while they were sick. If all symptoms were 'above the neck' (runny, stuffy nose or scratchy throat), the athlete could begin their exercise routine at a below normal intensity for 10 minutes. If such activity made them feel worse, they should stop exercising, but if they felt better, they should continue the training session. However, if any symptoms were 'below the neck' (muscle aches, cough, vomiting, diarrhoea or fever) training should be discontinued.

Since most athletic skin infections are spread through direct contact, competitors should be screened for skin lesions before participation in contact sports. Individuals infected with HSV should be excluded from competition until the lesions are no longer contagious (Duda 1989; Simon 1987). Oral aciclovir can be helpful in the relief of symptoms (Duda 1989; White 1992). A combination of sunscreen and aciclovir is recommended in individuals who are susceptible to herpes labialis (Nelson 1992). Other skin infections such as folliculitis and tinea pedis may be treated by a com- bination of general hygienic measures, antibiotic and antifungal treatments.

Coaches and athletes should be aware of the hazards of HIV infection. Special precautions should be used when dealing with body fluids. Open wounds should be covered immediately and any spills of blood on the floor or clothing should be cleaned as quickly as possible. According to the American Pediatric Society Policy Statement (1992), HIV infected individuals should be allowed full participation in sports programmes. Their serum positive status should not be disclosed, and the testing of athletes for HIV infection should be performed only on a voluntary basis.

\section{Conclusions}

Epidemiological data indicate some increase in the risk of upper respiratory tract and skin infections in athletes who are engaged in heavy training. The risk is further enhanced immediately following athletic competition, because of the psychological stress of the competitive event itself. Alterations in immune surveillance associated with intensive training and competition include a reduction in lymphocyte proliferation rates, a reduction in NK cell activity and low concentrations of immunoglobulins in serum and body secretions.

Data from both animal and human studies suggest that the intensity and duration of exercise, its timing relative to exposure to an infectious agent, and the type of infection all influence the effect of exercise on the immune response and vice versa. Overall, regular moderate physical conditioning apparently improves immunosurveillence, enhances resistance and decreases the duration of disease symptoms, but intensive training impairs the immune response, particularly when it is combined with the stress of major competition. Intensive or exhausting physical activity immediately before or during the early stages of an infection may increase the severity and lethality of a disease. Such an effect is greatest for viral infections, perhaps as a consequence of differences in the immune responses to viral and other types of infection. 
More research is needed on the interactions between athletic endeavour, immunity and infection, to improve guidelines for athletic training and competition. Researchers should seek the critical change in immune function that increases an athlete's susceptibility to infection. Based upon this finding, specific prophylactic measures may then be designed to minimise the adverse effects of heavy training and to maximise immunosurveillance during competition.

\section{References}

Allen A, King R. Occlusion, carbon dioxide, and fungal skin infections. Lancet 1: 360-362, 1978

American Academy of Pediatrics Policy Statement. HIV and sports. Human immunodeficiency virus [acquired immunodeficiency syndrome virus (AIDS)] in the athletic setting. Physician and Sportsmedicine 20 (5): 189-191, 1992

Badger GF, Dingle JH, Feller AE, Hodges RG, Jorden WS, et al. A study of illness in a group of Cleveland families. III. Introduction of respiratory infections into families. American Journal of Hygiene 51: 41-46, 1953

Bailey GW. The effect of fatigue upon the susceptibility of rabbits to intratracheal injections of type I pneumococcus. American Journal of Hygiene 5: 175-295, 1925

Balarajan R, Raleigh VS, Yuen P, Wheeler D, Machin D, Cartwright $R$. Health risks associated with bathing in sea water. British Medical Journal 303: 1444-1445, 1991

Baron RC, Hatch MH, Kleeman K, MacCormach NJ. Aseptic meningitis among members of a high school football team. An outbreak associated with echovirus infection 16 infection. Journal of the American Medical Association 248: 1724-1727, 1982a

Baron RC, Murphy FD, Greenberg HB, Davis CE, Bregman DJ, et al. Norwalk gastrointestinal illness. An outbreak associated with swimming in a recreational lake and secondary person-to-person transmission. American Journal of Epidemiology 115: 163-172, $1982 b$

Bartlett PC, Martin RJ, Cahill BR. Furunculosis in a high school football team. American Journal of Sports Medicine 10:371-374, 1982

Basler RSW. Skin lesions related to sports activity. Primary Care 10: 479-497, 1983

Becker TM, Kodis R, Bailey P, Lee F, Levandowski R, et al. Grappling with herpes: herpes gladiatorum. Journal of Sports Medicine and Physical Fitness 16: 665-669, 1988

Belongia EA, Goodman JL, Holland EJ, Andres CW, Homann SR, et al. An outbreak of herpes gladiatorum at a high-school wrestling camp. New England Journal of Medicine 325:906-910, 1991

Berg R, Ringertz O, Espmark $\AA$. Australian antigen in hepatitis among Swedish track finders. Acta Pathologica Microbiologica et Immunologica Scandinavica (Section B) 79: 423-427, 1971

Bergfeld WF. Dermatologic problems in athletes. Primary Care 11: 151-160, 1984

Berglund B, Hemmingson P. Infectious disease in elite cross-country skiers: a one-year incidence study. Clinical Sports Medicine 2: 19-23, 1990

Berk LS, Nieman DC, Tan A, Lee W. Complement and immunoglobulin levels in athletes vs sedentary controls. Abstract. Medicine and Science in Sports and Exercise 20: S19, 1988

Berk LS, Nieman DC, Youngberg WS, Arabatzis K, SimpsonWesterberg $\mathrm{M}$, et al. The effect of long endurance running on nat- ural killer cells in marathoners. Medicine and Science in Sports and Exercise 22: 207-212, 1990

Berk LS, Tan SA, Nieman DC, Eby WC. The suppressive effect of stress from acute exhaustive exercise on T lymphocyte helper/suppressor cell ratio in athletes and non-athletes. Abstract. Medicine and Science in Sports and Exercise 18: 706, 1986

Billigmann PW. Prophylaxe bronchopulmonaler Infektionen mit Immunoglobulin bei Hochleistungssportlern im Ausdauerbereich. Deutsche Zeitschrift für Sportmedizin 42: 17-19, 1991

Bowman JF. Infectious hepatits in a college football player. American Journal of Sports Medicine 4: 101-106, 1976

Budgett RG, Fuller GN. Illness and injury in international oarsmen. Clinical Sports Medicine 1: 57-61, 1989

Cabinian AE, Kiel RJ, Smith F, Ho KL, Khatib R, et al. Modification of exercise-aggravated coxsackievirus B3 murine myocarditis by $\mathrm{T}$ lymphocyte suppression in an inbred model. Journal of Laboratory and Clinical Medicine 115: 454-462, 1990

Calabrese LH, LaPerriere A. Human immunodeficiency virus infection, exercise and athletes. Sports Medicine 15: 6-13, 1993

Cannon JG. Exercise and resistance to infection. Journal of Applied Physiology 74: 973-981, 1993

Cannon JG, Kluger MJ. Exercise enhances survival rate in mice infected with Salmonella typhimurium (41830). Proceedings of the Society for Experimental Biology and Medicine 75: 518-521, 1984

Chalmers TC, Eckhardt RD, Reynolds WE, Cigarroa Jr JG, Deane $\mathrm{N}$, et al. The treatment of acute infectious hepatitis: controlled studies of the effects of diet, rest, and physical reconditioning on the acute course of the disease and on the incidence of relapses and residual abnormalities. Journal of Clinical Investigation 34: 1163 1235,1955

Clarke M. The constructs 'stress' and 'coping' as a rationale for nursing activities. Journal of Advanced Nursing 9: 267-275, 1984

Cole $\mathrm{G}$, Silverberg $\mathrm{N}$. The adherence of staphylococcus aureus to human corneocytes. Archives of Dermatology 122: 166-169, 1986

Conklin RJ. Common cutaneous disorders in athletes. Sports Medicine 9: 100-119, 1990

Cowles WN. Fatigue as a contributory cause of pneumonias. Boston Medical and Surgical Journal 179: 555-556, 1918

Crist DM, Mackinnon TL, Thompson RF, Atterbom HA, Egan PA. Physical exercise increases natural cellular-mediated tumor cytotoxicity in elderly women. Gerontology $35: 66-71,1989$

D'Alessio DJ, Minor TE, Allen CI, Tsiatis AA, Nelson DB. A study of the proportions of swimmers among well controls and children with enterovirus-like illness shedding or not shedding an enterovirus. American Journal of Epidemiology 113: 533-541, 1981

D'Angelo LJ, Hierholzer JC, Keenlyside RA, Anderson LJ, Martone WJ. Pharyngoconjunctival fever caused by adenovirus type 4: report of a swimming pool-related outbreak with recovery of virus from pool water. Journal of Infectious Diseases 140: 42-47, 1979

Daniels WL, Sharp DS, Wright JE, Vogel JA, Friman G, et al. Effects of virus infection on physical performance in man. Military Medicine 150: 8-14, 1985

Decker MD, Lybarger JA, Vaughn WK, Hutcheson RH, Schaffner W. An outbreak of staphylococcal skin infections among river rafting guides. American Journal of Epidemiology 124: 969-976, 1986

Diop Mar I. Infectious diseases in tropical climates. In Dirix et al. (Eds) The olympic book of sports medicine, pp. 583-588, Blackwell Scientific, Oxford, 1988

Dorman JM. Scrum strep. Correspondence. New England Journal of Medicine 305: 467, 1981

Dormer BA, Friedlander J. Physical efficiency and pulmonary tuberculosis. South African Journal of Science 38: 267-277, 1942

Douglas DJ, Hanssen PG. Upper respiratory infections in the conditioned athlete. Abstract. Medicine and Science in Sports and Exercise 10: 55, 1978

Drory Y, Kramer MR, Lev B. Exertional sudden death in soldiers. Medicine and Science in Sports and Exercise 23: 147-151, 1991 
Duda M. Herpes gladiatorum pins Wisconsin wrestlers. Physician and Sportsmedicine 17 (3): 50 and 255, 1989

Dufaux B, Order U, Geyer H, Hollmann W. C-reactive protein serum concentration in well trained athletes. International Journal of Sports Medicine 5: 102-106, 1984

Duncan W, McBride M, Knox J. Bacterial flora: the role of environmental factors. Journal of Investigative Dermatology 52: 479-484, 1969

Dyke LM, Merikangas UR, Brunton OC, Trask SG, Hetrick FM. Skin infection in wrestlers due to herpes simplex virus. Journal of the American Medical Association 194: 153-154, 1965

Edlund A. The effect of defined physical exercise in the early convalescence of viral hepatitis. Scandinavian Journal of Infectious Diseases 3: 189-196, 1971

Eichner ER. Infection immunity and exercise. What to tell patients. Physician and Sportsmedicine 21 (1): 125-135, 1993

Eichner R. Infectious mononucleosis: recognition and management in athletes. Physician and Sportsmedicine 15 (12): 61-71, 1987

Elson SH, Abelmann WH. Effects of muscular activity upon the acute myocarditis of $\mathrm{C} 3 \mathrm{H}$ mice infected with Trypanosoma cruzi. American Heart Journal 69: 629-636, 1965

Eskola J, Ruuskanen O, Soppi E, Viljanen K, Järvinen M, et al. Effect of sport stress on lymphocyte transformation and antibody formation. Clinical and Experimental Immunology 32: 339-345, 1978

Espersen GT, Elback A, Ernst E, Toft E, Kaalund S, et al. Effect of physical exercise on cytokines and lymphocyte subpopulation in human peripheral blood. Acta Pathologica Microbiologica et Immunologica Scandinavica 98: 395-400, 1990

Farber GA, Burks JW, Hegre AM, Brown GR. Football acne - an acneiform eruption. Cutis 20: 356-360, 1977

Field CJ, Gougeon R, Marliss EB. Circulating mononuclear cell numbers and function during intense exercise and recovery. Journal of Applied Physiology 71: 1089-1097, 1991

Fitzgerald L. Exercise and the immune system. Immunology Today 9: $337-339,1988$

Fitzgerald L. Overtraining increases the susceptibility to infection. International Journal of Sports Medicine 12: S5-S8, 1991

Fox JP, Hall CE, Cooney MK, Luce RE, Kronmal RA. The Seattle virus watch II. Objectives, study population and its observation, data processing and summary of illnesses. American Journal of Epidemiology 96: 270-285, 1972

Freeman MJ, Bergfeld WF. Skin diseases of football and wrestling participants. Cutis 20: 333-341, 1977

Friedman LS, O'Brien TF, Morse LJ, Chang LW, Wacker WEC, et al. Revisiting the Holy Cross football team hepatitis outbreak (1969) by serological analysis. Journal of the American Medical Association 254: 774-776, 1985

Friman G. Effect of acute infectious disease on isometric muscle strength. Scandinavian Journal of Clinical Laboratory Investigation 37: 303-308, 1977

Friman G, Ilbäck NG, Beisel WR, Crawford DJ. The effects of strenuous exercise in infection with Francisella tularensis in rats. Journal of Infectious Diseases 145: 706-714, 1982

Friman G, Ilbäck NG, Crawford DJ, Neufeld HA. Metabolic responses to swimming exercise in Streptococcus pneumoniae infected rats. Medicine and Science in Sports and Exercise 23: 415-421, 1991

Friman G, Wright JE, Ilbäck NG, Beisel WR, White JD, et al. Does fever or myalgia indicate reduced physical performance capacity in viral infections? Acta Medica Scandinavica 217: 353-361, 1985

Fry RW, Morton AR, Garcia-Webb P, Crawford GPM, Keast D. Biological responses to overload training in endurance sports. European Journal of Applied Physiology and Occupational Physiology 64: 335-344, 1992

Fry RW, Morton AR, Keast D. Acute intensive interval training and T-lymphocyte function. Medicine and Science in Sports and Exercise 24: $339-345,199$ la
Fry RW, Morton AR, Keast D. Overtraining in athletes: an update. Sports Medicine 12 (1): 32-65, 1991b

Gabriel H, Schmitt B, Urhausen A, Kindermann W. Adhäsionsmolekül LFA-1 auf der Zelloberfläche von Lymphozytensubpopulationen während und nach akuter körperlicher Belastung. Deutsche Zeitschrift für Sportmedizin 44 (10) 436-440, 1993

Gatmaitan BG, Chason JL, Lerner AM. Augmentation of thevirulence of murine coxsackie-virus B-3 myocardiopathy by exercise. Journal of Experimental Medicine 131: 1121-1136, 1970

Gentles JC, Evans EVG, Jones GR. Control of tinea pedis in a swimming bath. British Medical Journal 2: 577-580, 1974

Gentles JC, Jones GR, Roberts DT. Efficiency of miconazole in the topical treatment of tinea pedis. British Journal of Dermatology 93: 79-84, 1975

Glezen WP, Dewalt JL, Lindsay RL, Dillon HC. Epidemic pyoderma caused by nephritogenic streptococci in college athletes. Lancet 1 : 301-304, 1972

Green RL, Kaplan SS, Rabin BS, Syanitski CL, Zdziarski U. Immune function in marathon runners. Annals of Allergy 47: 73-75, 1981

Gwaltney JM, Hendley JO, Simon G, Jordan WS. Rhinovirus infections in an industrial population. I. The occurrence of illness. New England Journal of Medicine 275: 1262-1268, 1966

Hack V, Weiss M, Weicker H. Lymphozytensubpopulationen und Immunoglobulinkonzentration in Ruhe und nach erschöpfender Laufbelastung von hochausdauertrainierten Athleten während zweier Trainingsphasen. Deutsche Zeitschrift für Sportmedizin 44 (10) 430-440, 1993

Hanssen P. Vaccinia after boxing. Correspondence. Lancet 255: 819, 1948

Hargreaves ER. Poliomyelitis. Effect of exertion during the pre-paralytic stage. British Medical Journal 2: 1021-1022, 1948

Harter L, Frost F, Grunenfelder G, Perkins-Jones K, Libby J. Giardiasis in an infant and toddler swim class. American Journal of Public Health 74: 155-156, 1984

Heath GW, Macera CA, Nieman DC. Exercise and upper respiratory tract infections. Is there a relationship? Sports Medicine 14: 353365,1992

Heath GW, Ford ES, Craven TE, Macera CA, Jackson KL, et al. Exercise and incidence of upper respiratory tract infections. Medicine and Science in Sports and Exercise 23: 152-157, 1991

Hedfors E, Holm G, Öhnell B. Variation of blood lymphocytes during work studied by cell surface markers, DNA synthesis and cytotoxicity. Clinical and Experimental Immunology 24: 328-335, 1976

Hicks JH. Swimming and the skin. Cutis 19: 448-450, 1977

Hoadley AW, Knight OE. External otitis among swimmers and nonswimmers. Archives of Environmental Health 30: 445-448, 1975

Horstmann DM. Acute poliomyelitis. Relation of physical activity at the time of onset to the course of the disease. Journal of the American Medical Association 142: 236-239, 1950

Houston SD, Knox JM. Skin problems related to sports and recreational activities. Cutis 19: 487-491, 1977

Ilbäck NG, Fohlman J, Friman G. Exercise in Coxsackie B3 myocarditis: effects on heart lymphocyte subpopulations and the inflammatory reaction. American Heart Journal 117: 298-1302, 1989

Ilbäck NG, Friman G, Beisel WR. Biochemical responses of the myocardium and red skeletal muscle to Salmonella typhimurium. Clinical Physiology 3: 551-563, 1983

Ilbäck NG, Friman G, Beisel WR, Johnson AJ, Berendt RF. Modifying effects of exercise on clinical course and biochemical response of the myocardium in influenza and tularemia in mice. Infection and Immunity 45: 498-504, 1984

Ilbäck NG, Friman G, Crawford DJ, Neufeld HA. Effects of training on metabolic responses and performance capacity in Streptococcus pneumonia infected rats. Medicine and Science in Sports and Exercise $23: 422-427,1991$ 
Jokl E. The immunological status of athletes. Journal of Sports Medicine 14: 165-167, 1974

Joseph SW, Conway JB, Kalichman SG. Aquatic and terretrial bacteria in diving environments: monitoring and significance. Undersea Biomedical Research 18: 187-191, 1991

Kappel M, Tvede N, Galbo H, Haahr PM, Kjaer M, et al. Evidence that the effect of physical exercise on NK activity is mediated by epinephrine. Journal of Applied Physiology 70: 2530-2534, 1991

Kappus KD, Marks JS, Holman RC, Bryant JK, Baker C, et al. An outbreak of Norwalk gastroenteritis associated with swimming in a pool and secondary person-to-person transmission. American Journal of Epidemiology 116: 834-839, 1982

Karper WB, Boschen MB. Effects of exercise on acute respiratory tract infections and related symptoms. Geriatric Nursing 14: 15-18, 1993

Keast D, Cameron K, Morton AR. Exercise and immune response. Sports Medicine 5: 248-267, 1988

Keast D, Morton AR. Long term exercise and immune functions. In Watson \& Eisinger (Eds) Exercise and disease, pp. 89-120, CRC Press, Ann Arbor, 1992

Kiel RJ, Smith FE, Chason J, Khatib R, Reyes MD. Coxsackievirus B3 myocarditis in $\mathrm{C} 3 \mathrm{H} / \mathrm{HeJ}$ mice: Description of an inbred model and the effect of exercise on the virulence. European Journal of Epidemiology 5: 348-350, 1989

Klempner MS, Gallin JI. Inhibition of neutrophil Fc receptor function by corticosteroids. Clinical and Experimental Immunology 34: 137-142, 1978

Krinkler DM, Zilberg B. Activity and hepatitis. Lancet 2: 1046-1047, 1966

Kumar V, Cotran RS, Robbins SL. Basic pathology, 5th ed., WB Saunders, Toronto, 1992

LaPerriere AR, Antoni MH, Schneiderman N, Ironson G, Klimas N, et al. Exercise intervention attenuates emotional distress and natural killer cell decrements following notification of positive serologic status for HIV-1. Biofeedback and Self-Regulation 15: 229-241, 1990

LaPerriere A, Fletcher MA, Antoni MH, Klimas NG, Schneiderman N. Aerobic exercise training in an AIDS risk group. International Journal of Sports Medicine 12: S53-S57, 1991

Lee DJ, Meehan RT, Robinson C, Mabry TR, Smith ML. Immune responsiveness and risk of illness in US Air Force Academy cadets during basic cadet training. Aviation, Space and Environmental Medicine 63: 517-523, 1992

Legwold G. Cross-country skiers may be susceptible to URIs. Physician and Sportsmedicine 10 (4): 42, 1982

Lenaway DD, Brockmann R, Dolan GJ, Cruz-Uribe F. An outbreak of an enterovirus-like illness at a community wading pool: implications for public health inspection programs. American Journal of Public Health 79: 889-890, 1989

Lerner MA, Wilson FM. Virus myocardiopathy. Progress in Medical Virology 15: 63-91, 1973

Levinson SO, Mitzer A, Lewin P. Effect of fatigue, chilling and mechanical trauma on resistance to experimental poliomyelitis. American Journal of Hygiene 42: 204-213, 1945

Lewicki R, Tchórzewski H, Denys A, Kowalska M, Golinska A. Effect of physical exercise on some parameters of immunity in conditioned sportsmen. International Journal of Sports Medicine 8: $309-314,1987$

Lewicki R, Tchórzewski H. Majewska E, Nowak Z, Baj Z. Effect of maximal physical exercise on T-lymphocyte subpopulations and on interleukin (IL 1) and interleukin 2 (IL 2) production in vitro. International Journal of Sports Medicine 9: 114-117, 1988

Liesen H, Uhlenbrack G. Sports immunology. Sport Science Review 1: 94-116, 1992

Linde F. Running and upper respiratory tract infections. Scandinavian Journal of Sport Science 9: 21-23, 1987
Linenger JM, Flink S, Thomas B, Johnson CW. Musculoskeletal and medical morbidity associated with rigorous physical training. Clinical Journal of Sports Medicine 3: 229-234, 1993

Liu YG, Wang SY. The enhancing effect of exercise on the production of antibody to Salmonella typhi in mice. Immunology Letters 14: $117-120,1987$

Ludlam H, Cookson B. Scrum kidney: epidemic pyoderma caused by a nephritogenic streptococcus pyogenes in a rugby team. Lancet 2: 331-333, 1984

Macarthur RD, Levine SD, Birk TJ. Supervised exercise training improves cardiopulmonary fitness in HIV infected persons. Medicine and Science in Sports and Exercise 25: 684-688, 1993

Mackinnon LT. Exercise and immunology, pp. 1-113, Human Kinetics Books, Champaign, 1992

Mackinnon L, Ginn E, Seymour G. Temporal relationship between exercise-induced decreases in salivary IgA concentrations and subsequent appearance of upper respiratory illness in elite athletes. Abstract. Medicine and Science in Sports and Exercise 23: S45, 1991

Mackinnon LT, Ginn E, Seymour G. Decreased salivary immunoglobulin A secretion rate after intense interval exercise in elite kayakers. European Journal of Applied Physiology and Occupational Physiology 67: 180-184, 1993

Mackinnon L, Hooper S, Gordon R, Tunney T. Immune parameters and stress hormones in overtrained swimmers. Abstract. Medicine and Science in Sports and Exercise 24: S64, 1992

Mackinnon LT, Jenkins DG. Decreased salivary immunoglobulins after intense interval exercise before and after training. Medicine and Science in Sports and Exercise 25: 678-683, 1993

Mackinnon L, Van Ash CA, Tomasi TB. Decreased levels of secretory immunoglobulins following prolonged exercise. Abstract. Medicine and Science in Sports and Exercise 18: S40, 1986

Makintubee S, Mallonee J, Istre GR. Shigellosis outbreak associated with swimming. American Journal of Public Health 77: 166-168, 1987

Maré JB, Keyzer CM, Becker WB. Troumatise Herpesvirus hominisinfeksie tydens rugby (Herpes Venatorum) 'n Bespreking van Vier Gevalle. South African Medical Journal 54: 752-754, 1978

McDowell SL, Hughes RA, Hughes RJ, Housh DJ, Housh TJ, et al. The effect of exhaustive exercise on salivary immunoglobulin A. Journal of Sports Medicine and Physical Fitness 32: 412-415, 1992

Midtvedt T, Midtvedt K. Sport and infection. Scandinavian Journal of Social Medicine 29 (Suppl.): 241-244, 1982

Mills J, Hauer L, Gottlieb A, Dromgoole S, Spruance S. Recurrent herpes labialis in skiers. Clinical observations and effect of sunscreen. American Journal of Sports Medicine 15: 76-78, 1987

Morgan WP. Affective beneficence of vigorous physical activity. Medicine and Science in Sports and Exercise 17: 94-100, 1985

Morse LJ, Bryan JA, Hurley JP, Murphy JF, O'Brien TF, et al. The Holy Cross college football team Hepatitis outbreak. Journal of the American Medical Association 219: 706-708, 1972

Morton AR, Fitch KD. Exercise-induced bronchial obstruction. In Torg et al. (Eds) Current therapy in sports medicine 2, pp. 53-59, BC Decker Inc., Burlington, 1990

Müns G, Liesen H, Riedel H, Bergmann K-Ch. Influence of long distance running on IgA in nasal secretion and saliva. Deutsche Zeitschrift für Sportsmedizin 40: 63-65, 1989

Munschek H. Der plötzliche Tod beim Sport infolge Myocarditis. Sportarzt Sportmedizin 27: 201-210, 1976

Nash HL. Can exercise make us immune to disease? Physician and Sportsmedicine 14 (3): 251-253, 1986

Nefzger MD, Chalmers TC. The treatment of acute infectious hepatitis: ten-year follow-up study of the effects of diet and rest. American Journal of Medicine 35: 299-309, 1963

Nelson MA. Stopping the spread of herpes simplex. A focus on Wrestlers. Physician and Sportsmedicine 20 (10): 117-127, 1992 
Nicholls EE, Spaeth RA. The relation between fatigue and the susceptibility of guinea pigs to injections of Type I pneumococcus. American Journal of Hygiene 2: 527-535, 1922

Nieman DC, Berk LS, Simpson-Westerberg M, Arabatzis K, Youngberg $S$, et al. Effects of long-endurance running on immune system parameters and lymphocyte function in experienced marathoners. International Journal of Sports Medicine 10: 317-323, 1989a

Nieman DC, Johanssen LM, Lee JW. Infectious episodes in runners before and after a roadrace. Journal of Sports Medicine and Physical Fitness 29: 289-296, 1989b

Nieman DC, Johanssen LM, Lee JW, Arabatzis K. Infectious episodes in runners before and after the Los Angeles marathon. Journal of Sports Medicine and Physical Fitness 30: 316-328, 1990a

Nieman DC, Nehlsen-Cannarella SL. The effects of acute and chronic exercise on immunoglobulins. Sports Medicine 11: 183-201, 1991

Nieman DC, Nehlsen-Cannarella SL. Exercise and infection. In Watson \& Eisinger (Eds) Exercise and disease, pp. 121-148, CRC Press, Boca Raton, 1992

Nieman DC, Nehlsen-Cannarella SL, Markoff PA, Balk-Lamberton $\mathrm{AJ}$, Yang $\mathrm{H}$, et al. The effects of moderate exercise training on natural killer cells and acute upper respiratory tract infections. International Journal of Sports Medicine 11: 467-473, 1990b

Nieman DC, Tan SA, Lee JW, Berk LS. Complement and immunoglobulin levels in athletes and sedentary controls. International Journal of Sports Medicine 10: 124-128, 1989c

Niinimaa V. Figure skating: what do we know about it? Physician and Sportsmedicine 10 (1): 51-56, 1982

Niinimaa V, Cole P, Mintz S, Shephard RJ. The switching point from nasal to oronasal breathing. Respiration Physiology 42: 61-71, 1980

Niizeki K, Kano O, Kondo Y. An epidemic study of molluscum contagiosum: relationship to swimming. Dermatologica 169: 197-198, 1984

Oppenheimer EH, Spaeth RE. The relation between fatigue and the susceptibility of rats towards a toxin and infection. American Journal of Hygiene 24: 51-66, 1922

Order V, Riedel H, Liesen H, Widenmayer W, Hellwig T, et al. Leucocytes and lymphocyte subsets. Deutsche Zeitschrift für Sportmedizin 40: 22-29, 1989

Österback L, Qvarnberg Y. A prospective study of respiratory infections in 12-year old children. Acta Paediatrica Scandinavica 76: 944-949, 1987

Paffenbarger RS, Hyde RT, Wing AL, Lee IM, Jung DL, et al. The association of changes in physical activity level and other lifestyle characteristics with mortality among men. New England Journal of Medicine 328: 538-545, 1993

Paffenbarger RS, Hyde RT, Wing AL, Steinmetz CH. A natural history of athleticism and cardiovascular health. Journal of the American Medical Association 252: 491-495, 1984

Parry-Billings M, Blomstrand E, McAndrew N, Newsholme E. A communicational link between skeletal muscle, brain and cells of the immune system. International Journal of Sports Medicine 11: S122-128, 1990

Parry-Billings M, Budgett R, Koutedakis Y, Blomstrand E, Brooks $S$, et al. Plasma amino acid concentrations in the over-training sysdrome: possible effects on the immune system. Medicine and Science in Sports and Exercise 24: 1353-1358, 1992

Pedersen BK, Tvede N. Immunsystem og fysisk traening. Ugeskrift for Laeger 155: 856-862, 1993

Pedersen BK, Tvede N, Klarlund K, Christensen LC, Hansen FR, et al. Indomethacin in vivo and in vitro abolishes post-exercise suppression of natural killer cell activity in peripheral blood. International Journal of Sports Medicine 11: 127-131, 1990

Peters EM, Bateman ED. Ultramarathon running and upper respiratory tract infections. South African Medical Journal 64: 582-584, 1983

Phillips MM, Robinowitz M, Higgins JRM, Boran MKJ, Reed T, et al. Sudden cardiac death in airforce recruits. A twenty year review. Journal of the American Medical Association 256: 2696-2699, 1986
Porter JD, Ragazzoni HP, Buchanon JD, Waskin HA, Juranek DD, et al. Giardia transmission in a swimming pool. American Journal of Public Health 78: 659-662, 1988

Porter PS, Baughmann RD. Epidemiology of herpes simplex among wrestlers. Journal of the American Medical Association 194: 150152,1965

Postlewaite R, Watt JA. Features of molluscum contagiosum in the north-east of Scotland and in Fijian village settlements. Journal of Hygiene 65: 281-291, 1967

Resnik SS, Lewis LA, Cohen BH. The athlete's foot. Cutis 20: 351355,1977

Reyes MP, Ho KL, Smith F, Lerner AM. A mouse model of dilatedtype cardiomyopathy due to Coxsackievirus B3. Journal of Infectious Diseases 144: 232-236, 1981

Reyes MP, Lerner AM. Interferon and neutralizing antibody in sera of exercised mice with coxsackie B-3 myocarditis (39204). Proceedings of the Society for Experimental Biology and Medicine 151: 333-338, 1976

Rigsby LW, Dishman RK, Jackson AW, Maclean GS, Raven PB. Effects of exercise training on men seropositive for the human immunodeficiency virus-1. Medicine and Science in Sports and Exercise 24: 6-12, 1992

Roberts JA. Viral illness and sports performance. Sports Medicine 3: 296-303, 1986

Roitt I, Brostoff J, Male D. Immunology, pp. 1.1 and 10.10-10.11, CV Mosby, Toronto, 1985

Rosenbaum HE, Harford CG. Effect of fatigue on susceptibility of mice to poliomyelitis. Proceedings of the Society for Experimental Biology and Medicine 83: 678-681, 1953

Rosenberg ML, Hazlet KK, Schaefer J, Wells JG, Pruneda RC. Shigellosis from swimming. Journal of the American Medical Association 236: 1849-1852, 1976

Russell RW. Poliomyelitis. The pre-paralytic stage, and the effect of physical activity on the severity of paralysis. British Medical Journal 2: 1023-1028, 1947

Russell RW. Paralytic poliomyelitis. The early symptoms and the effect of physical activity on the course of the disease. British Medical Journal 1: 465-471, 1949

Rylander R. Pulmonary defense mechanisms to airborne bacteria. Acta Physiologica Scandinavica 306 (Suppl.): 6-85, 1968

Schlenzig C, Jäger H, Rieder H. Einfluss von Sporttherapie auf die zelluläre Immunabwehr und die Psych HIV-infizierter Männer. Deutzche Zeitschrift für Sportmedizin 41: 156-160, 1990

Schouten WJ, Verschuur R, Kemper HCG. Physical activity and upper respiratory tract infections in a population of young men and women: the Amsterdam growth and health study. International Journal of Sports Medicine 9: 451-455, 1988

Selling B, Kibrick S. An outbreak of herpes simplex among wrestlers (herpes gladiatorum). New England Journal of Medicine 270: 979 982, 1964

Seyfried PL, Tobin RS, Brown NE, Ness PF. A prospective study of swimming related illness. I. Swimming associated health risk. American Journal of Public Health 75: 1068-1070, 1985

Sharp JCM, Girdwood RWA, Watt B, Walker E, Fagan KE, et al. Infections in sport. British Journal of Sports Medicine 22: 117-121, 1988

Shephard RJ. Sleep, biorhythms and human performance. Sports Medicine 1: 11-37, 1984

Shephard RJ, Shek PN. Athletic competition and susceptibility to infection. Clinical Journal of Sports Medicine 3: 75-77, 1993

Shephard RJ, Verde TJ, Thomas SG, Shek P. Physical activity and the immune system. Canadian Journal of Sport Sciences 16: 163185,1991

Shinkai S, Shore S, Shek PN, Shephard RJ. Acute exercise and immune function. Relationship between lymphocyte activity and changes in subset counts. Correspondence. International Journal of Sports Medicine 13: 452-461, 1992 
Shute P, Jeffries DJ, Maddocks AC. Scrum-pox caused by herpes simplex virus. British Medical Journal 2: 1629, 1979

Simon HB. Exercise and infection. Physician and Sportsmedicine 15 (10): 135-141, 1987

Sklarek HM, Mantovani RP, Erens E, Heisler D, Niederman MS, et al. AIDS in a bodybuilder using anabolic steroids. Correspondence. New England Journal of Medicine 311: 1701, 1984

Smith AD, Micheli LJ. Injuries in competitive figure skaters. Physician and Sportsmedicine 10 (1): 36-47, 1982

Smith JA, Telford RD, Mason IB, Weidemann MJ. Exercise training and neutrophil microbicidal activity. International Journal of Sports Medicine 11: 179-187, 1990b

Smith JK, Chi DS, Krish G, Reynolds S, Cambron G. Effects of exercise on complement activity. Annals of Allergy 65: 304-310, $1990 \mathrm{a}$

Sosin DM, Gunn RA, Ford WL, Skaggs JW. An outbreak of furunculosis among high school athletes. American Journal of Sports Medicine 17: 828-832, 1989

Spence DW, Galantino MLA, Mossberg KA, Zimmerman SO. Progressive resistance exercise: effect on muscle function and anthropoimetry of a select AIDS population. Archives of Physical Medicine and Rehabilitation 71: 644-648, 1990

Spruance SL, Hamill ML, Hoge WS, Davis LG, Mills J. Acyclovir prevents reactivation of herpes simplex labialis in skiers. Journal of the American Medical Association 260: 1597-1599, 1988

Strauss RH, Lanese RR, Leizman DJ. Illness and absence among wrestlers, swimmers and gymnasts at a large university. American Journal of Sports Medicine 16: 653-655, 1988

Thong YH. Immunomodulation by antimicrobial agents. In Jeljaszewicz \& Pulverer (Eds) Antimicrobial agents and immunity, pp. 91-93, Academic Press, Toronto, 1986

Thornton JS. Common concerns about the common cold. Physician and Sportsmedicine 18 (6): 120-126, 1990

Thorp GD. Basketball exercise and secretary immunoglobulin A. European Journal of Applied Physiology and Occupational Physiology 63: 312-314, 1991

Tilles JG, Elson SH, Shaka JA, Abelmann WH, Lerner MA, et al. Effect of exercise on Coxsackie A9 myocarditis in adult mice. Proceedings of the Society for Experimental Biology and Medicine 117: 777-782, 1964

Tomasi TB, Trudeau FB, Czerwinski D, Erredge S. Immune parameters in athletes before and after strenuous exercise. Journal of Clinical Immunology 2: 173-178, 1982

Tonneson E, Christensen NJ, Brinklov MM. Natural killer cell activity during cortisol and adrenaline infusion in healthy volunteers. European Journal of Clinical Investigation 17: 497-503, 1987

Torre D, Sampietro C, Ferraro G, Zeroli C, Speranza F. Transmission of HIV-1 infection via sports injury. Correspondence. Lancet 335 : 1105,1990
Turner M, Istre GR, Beauchamp H, Baum M, Arnold S. Community outbreak of adenovirus type $7 \mathrm{a}$ infections associated with a swimming pool. Southern Medical Journal 80: 712-715, 1987

Verbov J, Lowe NJ. Herpes rugbeiorum. Lancet 2: 1523-1524, 1974

Verde TJ. Short term exercise and immune function. In Watson \& Eisinger (Eds) Exercise and disease, pp. 71-88, CRC Press, Ann Arbor, 1992

Verde TJ, Thomas S, Shek P, Shephard RJ. Responses of lymphocyte subsets, mitogen-stimulated cell proliferation, and immunoglobulin synthesis to vigorous exercise in well trained athletes. Clinical Journal of Sports Medicine 2: 87-92, 1992a

Verde TJ, Thomas S, Shephard RJ. Potential markers of heavy training in highly trained distance runners. British Journal of Sports Medicine 26: 167-175, 1992b

Verde TJ, Thomas SG, Shephard RJ, Miles DS, Cox MH. Cumulative proliferative response of the cell-mediated response to exercise. Abstract. Medicine and Science in Sports and Exercise 23: S46, 1991

Verde TJ, Thomas S, Moore RW, Shek P, Shephard RJ. Immune responses and increased training of the elite athlete. Journal of Applied Physiology 73: 1494-1499, 1992c

Von Schirnding YER. Sewage to sea - what are the health implications. South African Medical Journal 76: 642-634, 1989

Weinstein L. Poliomyelitis - a persistent problem. New England Journal of Medicine 288: 370-372, 1973

Weiss M. Infekteprophylaxe mit polyvalenten Immunoglobulin: Diskussion auslässlich der Anwendung vor der Olympiade 1992 bei der deutschen Box-Nationalstaffel. Deutsche Zeitschrift für Sportmedizin 44: 466-471, 1993

Welch MJ, Wheeler L. Aerobic capacity after contracting infectious mononucleosis. Journal of Orthopaedic and Sports Physical Therapy 8: 199-202, 1986

Wheeler CE, Cabaniss WH. Epidemic cutaneous herpes simplex in wrestlers (herpes gladiatorum). Journal of the American Medical Association 194: 145-149, 1965

White J. Vigilance vanquishes herpes gladiatorum. Physician and Sportsmedicine 20 (1): 56, 1992

White WB, Grant-Kels JM. Transmission of herpes simplex type I infection in rugby players. Journal of the American Medical Association 252: $533-535,1984$

Correspondence and reprints: Professor Roy J. Shephard, School of Physical and Health Education, 320 Huron Street, Toronto, Ontario M5S 1A1, Canada. 